\title{
Techno-economic comparison of ethanol and electricity coproduction schemes from sugarcane residues at existing sugar mills in Southern Africa
}

\author{
Abdul M Petersen, Mathew C Aneke and Johann F Görgens ${ }^{*}$
}

\begin{abstract}
Background: The economics of producing only electricity from residues, which comprise of surplus bagasse and $50 \%$ post-harvest residues, at an existing sugar mill in South Africa was compared to the coproduction of ethanol from the hemicelluloses and electricity from the remaining solid fractions. Six different energy schemes were evaluated. They include: (1) exclusive electricity generation by combustion with high pressure steam cycles (CHPSC-EE), (2) biomass integrated gasification with combined cycles (BIGCC-EE), (3) coproduction of ethanol (using conventional distillation (CD)) and electricity (using BIGCC), (4) coproduction of ethanol (using CD) and electricity (using CHPSC), (5) coproduction of ethanol (using vacuum distillation (VD)) and electricity (using BIGCC), and (6) coproduction of ethanol (using VD) and electricity (using CHPSC). The pricing strategies in the economic analysis considered an upper and lower premium for electricity, on the standard price of the South African Energy Provider Eskom' of 31 and 103\% respectively and ethanol prices were projected from two sets of historical prices.

Results: From an energy balance perspective, ethanol coproduction with electricity was superior to electricity production alone. The VD/BIGCC combination had the highest process energy efficiency of $32.91 \%$ while the CHPSC-EE has the lowest energy efficiency of $15.44 \%$. Regarding the economic comparison, it was seen that at the most conservative and optimistic pricing strategies, the ethanol production using VD/BIGCC had the highest internal rate of returns at 29.42 and $40.74 \%$ respectively.

Conclusions: It was shown that bioethanol coproduction from the hemicellulose fractions of sugarcane residues, with electricity cogeneration from cellulose and lignin, is more efficient and economically viable than the exclusive electricity generation technologies considered, under the constraints in a South African context.
\end{abstract}

\section{Background}

Sugarcane processing industries in Southern Africa generate bagasse at a yield of 0.30 tons per ton of cane processed [1]. In most sugar mills in Southern Africa, the generated bagasse is mostly burnt to provide heat and electricity for the sugar milling operations [1,2]. South African sugar mills (from crushing to raw sugar production) typically have poor efficiency and the average steam demand is 0.58 tons per ton of sugarcane processed [3] (58\% on cane). When such process designs are coupled with low efficiency biomass-to-energy conversion systems, then no surplus bagasse is generated by the sugar mill and therefore no export of electricity occurs [4,5]. If efficient

\footnotetext{
*Correspondence: jgorgens@sun.ac.za

Department of Process Engineering, University of Stellenbosch, Cnr Banghoek Road \& Joubert Street, Stellenbosch 7600, South Africa
}

sugar mills that have steam demands below $40 \%[5,6]$ are coupled with efficient systems that convert biomass to energy [6], then excess bagasse becomes available. This excess, if combined with other post-harvest residues like sugarcane trash, could provide the feedstock for the production of bio-energetic products in an integrated facility. The costs associated with the utilization of such residues would include the cost of collection and transport, and the investment costs required to upgrade the energy efficiency of existing sugar mills to enable the liberation of surplus bagasse. These costs are significantly lower than the purchasing costs of biomass [7] that hinders the economic viability of 'stand-alone' facilities for biomass conversion to energy [8].

The low efficiency biomass-to-energy systems in older cane milling operations utilized combustion systems that 
had raised steam to pressures of between 15 and 22 bar $[5,9]$. Such systems also provided a low cost means of disposing of bagasse $[1,9]$ at a time when exporting electricity was not economically interesting. For that means, combustion with high pressure steam cycles allowed for greater turbine efficiency in the conversion of steam to electricity and thus, pressures of 82 to 85 bar $[1,10]$ would have typically been preferred. At a pressure of 60 bar, it has been shown that a net electricity export of 72 $\mathrm{kW}$ (per ton of cane processed per hour) was possible for an efficient sugarcane mill, where a steam demand of 0.4 tons per ton of cane was required [5]. This amount of export electricity could have been increased substantially if the harvesting residues (trash) was also considered $[5,7,11]$. The electrical efficiencies resulting from biomass power plants utilizing combustion and high pressure steam cycles are reported to be between 23 and $26 \%$ on an HHV (Higher Heating Value) basis [12,13], while efficiencies reported for Biomass Integrated Gasification and Combined Cycles system (BIGCC) were at 34 to $40 \%$ [14]. The implementation of BIGCC in industry has been limited due to the reportedly high capital investment that is required $[12,13,15]$. The capital estimates of BIGCC systems in previous techno-economic assessments $[12,13,16]$ however, were based on the estimates in a period where BIGCC technology was still new (1990 to the early 2000s) [17], and thus, capital estimates based on the vendor quotes in this period would have reflected the pioneer plant costs. A capital estimate based on a matured estimate could be significantly lower than the pioneer estimate [18].

As an alternative to the conversion of all of the available lignocellulose residues to electricity, a fraction of the bagasse and post-harvest residues could be used to produce ethanol, with co-generation of electricity. The hemicellulose, which makes up about 20 to 35\% [19] of the biomass matrix, can be solubilized by steam explosion or dilute acid hydrolysis and converted to ethanol, while the remaining cellulose-lignin fractions are converted to heat and power $[20,21]$. This scenario for the coproduction of ethanol and electricity from lignocellulose has been proposed for the South African industry [20], but a detailed process flow sheet and technoeconomic investigation of such for existing sugar mills is not available. Of particular interest would be the techno-economic comparison of coproduction of ethanol and electricity against a scenario where the residues are used exclusively for electricity generation. Previous studies have compared electricity generation alone with the complete lignocellulose conversion to ethanol (hemicellulose and cellulose) as options for integration with sugar mills [22] and autonomous distilleries [7,11]. The ethanol generation scheme in this study builds on the concept of 'value prior to combustion' that has previously been evaluated as a green-field (stand-alone) scenario [21].
There has been a considerable success in developing microbial strains that efficiently converts pentose-rich hydrolysates to ethanol [23], which is the key area of importance if the proposed technology is to be feasible. Using adapted strains of a the native pentose fermenting yeast Pichia stipitis, Kurian et al. [24] converted $82.5 \%$ of the hemicellulose sugars in a hydrolysate derived from sorghum bagasse that contained $92 \mathrm{~g} / \mathrm{l}$ of dissolved sugars, while Nigam [25] converted $80.0 \%$ in an acid hydrolysate from wheat straw, containing $80 \mathrm{~g} / \mathrm{l}$ sugars. The development of robust recombinant strains, such as the Saccharomyces cerevisiae TMB400, have resulted in pentose conversions in excess of $85 \%$ in toxic environments in simultaneous saccharification and fermentation experiments [26]. More recently, the National Renewable Energy Laboratory (NREL) achieved an ethanol yield of $92 \%$ on hemicellulose sugars in a toxic enzymatic hydrolysate that contained a total of about $150 \mathrm{~g} / \mathrm{l}$ of sugars, using the Zymomonas mobilis strain that was genetically engineered by Du Pont [27]. Thus, fermentation technology for converting pentose sugars in hydrolysates to ethanol has been successfully demonstrated on a laboratory scale.

The present study provides a detailed techno-economic comparison of scenarios that entail ethanol coproduction with export electricity, produced either by combustion or BIGCC systems, against those that produce only export electricity using the same systems. For either scenario, the upgrading costs of the existing sugar mill to achieve an energy efficiency of 0.40 ton of steam per ton of cane, is included in the capital investments considered in the economic analysis. The development of process models for the ethanol coproduction scenario will be based on established flow sheets and process performances for lignocellulosic ethanol $[28,29]$, and will also consider various processing options to ensure the most energy efficient and economical flow sheet. The projects are assumed to be in Kwa-Zulu Natal where the sugar cane crushing plants are concentrated. All South African legislations would apply.

Energy efficiency for all of the scenarios will be maximized through pinch point analysis (PPA) for the heat integration of the processing streams [30-32]. This approach will ensure that the energy utilities for ethanol production are kept to a minimum $[29,30]$, consequently maximizing the export electricity while still providing the energy requirements of the (energy efficient) mill [33]. From the process simulations (mass- and energy-balances) for the various scenarios economic evaluations, incorporating capital and operational costs as well as sales prices, will be performed from an economic risk perspective [34-37]. These methods are based on Monte Carlo simulations that are super-imposed on standard methods for process economic methods, in order to account for the risks associated with the fluctuations in economic variables, thereby 
providing not only the estimates for investment returns, but also the probability of achieving economic success.

\section{Results and discussion}

Technical evaluation

Six scenarios for the production of electricity from sugarcane residues, either as the only energy product or with coproduction of ethanol from hemicellulose, were evaluated through process modelling to estimate process energy efficiency and economics. The results of the energy characteristics for the various process alternatives that have been optimized by pinch point analysis are presented in Table 1. Furthermore, the amount of steam generated by the heat and power facility in each scenario, whether this facility forms an exclusive electricity scenario or an energy generation section of an ethanol coproduction scenario, is presented. If the facility utilizes the Combustion with High Pressure Steam Cycles (CHPSC) technology, then the gross steam generation refers to gross amount of steam generated by the biomass-fired boiler. If the heat and power plant utilizes the BIGCC technology then the gross steam generation refers to the steam generated by the heat recovery steam generator (HRSG) that recovers heat from the gas turbine's exhaust. The steam contingency refers to the amount of steam that is reserved once all the demands of the sugar mill and ethanol plants (in the case of ethanol coproduction scenarios) are met, and is essentially an indication of the operating leeway the scenario offers in terms of meeting steam when fluctuations in the plant occur. According to Pellegrini et al. [38], the maximum fluctuation of the steam demand in a sugar mill was measured at $2 \%$.

The ethanol production rate of all the coproduction scenarios averages $9591 \mathrm{l} / \mathrm{hr}$, which would equate to 62 million liters per annum. Given that the total consumption of road transport fuel in South Africa is about 23 billion liters per annum [39], this production rate would represent $0.27 \%$ of road transport fuels. This production rate equates to an ethanol yield of 35 liters per ton of cane crushed, where the hemicellulose fraction of the bagasse and $50 \%$ of the trash generated is converted to ethanol. With regards to the exclusive electricity generation, the BIGCC-EE and CHPSC-EE (EE - exclusive electricity production using BIGCC and CHPSC respectively) scenarios generated $88.63 \mathrm{MW}$ and $53.43 \pm 2.43 \mathrm{MW}$ of electricity (MWe) respectively. Given that the total output of electricity supplied to the national grid is $34 \mathrm{GW}$ [40], then the contribution to the grid would be $0.22 \%$ and $0.13 \%$ for the BIGCC-EE and CHPSC-EE respectively. The coproduction of ethanol with electricity from sugarcane

Table 1 Bio-energetic product yields, utility demands and energy efficiencies (optimized by pinch point analysis) (CD/ CHPSC - Ethanol Production with Conventional Distillation with energy generation from pretreatment residues using CHPSC; CD/BIGCC - Ethanol production with Conventional Distillation with energy generation from pretreatment residues using BIGCC; VD/CHPSC - Ethanol Production with Vacuum Distillation with energy generation from pretreatment residues using CHPSC; VD/BIGCC - Ethanol production with Vacuum Distillation with energy generation from pretreatment residues using BIGCC; CHPSC-EE - Exclusive electricity generation from residues using CHPSC; CHPSC-EE (Dryer) - Exclusive electricity generation from residues using CHPSC where biomass is dried; BIGCC-EE Exclusive electricity generation from residues using BIGCC)

\begin{tabular}{|c|c|c|c|c|c|c|c|}
\hline \multirow[b]{2}{*}{$\underline{\text { Scenarios }}$} & \multicolumn{4}{|c|}{ Ethanol cogeneration } & \multicolumn{3}{|c|}{ Exclusive electricity } \\
\hline & CD/CHPSC & CD/BIGCC & VD/CHPSC & VD/BIGCC & CHPSC-EE & CHPSC -EE (Dryer) & BIGCC-EE \\
\hline \multicolumn{8}{|l|}{ Net Outputs } \\
\hline Bioethanol Production (I/hr) & 9601 & 9577 & 9599 & 9575 & & & \\
\hline Electricity Production (MW) & 22.06 & 33.94 & 23.42 & 46.47 & 51.00 & 55.85 & 88.63 \\
\hline \multicolumn{8}{|l|}{ Steam Generation and Requirements } \\
\hline Gross Steam Generation (tons/hr) & 204.58 & 146.43 & 204.58 & 146.42 & 277.22 & 294.71 & 191.98 \\
\hline Mill Steam Demand (tons/hr) & 120.00 & 120.00 & 120.00 & 120.00 & 120.00 & 120.00 & 120.00 \\
\hline Ethanol Generation Steam Demand (tons/hr) & 51.06 & 51.06 & 30.25 & 30.25 & & & \\
\hline Steam Contingency (tons/hr) & 33.53 & -24.63 & 54.34 & -3.83 & 157.22 & 174.71 & 71.98 \\
\hline As percentage of Total Steam Demand & 19.60 & -14.40 & 36.17 & -2.55 & 131.02 & 145.59 & 59.99 \\
\hline \multicolumn{8}{|l|}{ Electricity Generation and Requirements } \\
\hline Gross Electricity Generation (MW) & 38.52 & 187.50 & 40.76 & 187.51 & 65.49 & 70.50 & 263.36 \\
\hline Power (MW) & 1.17 & 122.63 & 1.36 & 122.63 & 2.00 & 2.15 & 162.24 \\
\hline Ethanol Utilities (MW) & 2.81 & 18.44 & 3.49 & 5.91 & & & \\
\hline Mill Electricity Demand (MW) & 12.49 & 12.49 & 12.49 & 12.49 & 12.49 & 12.49 & 12.49 \\
\hline Net Energy Efficiency & $25.57 \%$ & $29.17 \%$ & $25.98 \%$ & $32.91 \%$ & $15.44 \%$ & $16.86 \%$ & $26.83 \%$ \\
\hline
\end{tabular}


residues available at sugar mills would reduce the potential electrical export by approximately $54 \%$ on average.

With regards to the steam generation and demand, it is seen that the gross generation of steam in the BIGCCEE process is $32.86 \%$ less than the amount of the CHPSCEE process, primarily because BIGCC technology is meant to maximize electricity generation, rather than steam generation. The steam generated by the heat and power generation facilities of the ethanol coproduction scenarios are $28.4 \%$ lower when compared to their exclusive electricity counterparts. The major implication of this reduction for steam generation was that when BIGCC technology was coupled with ethanol coproduction, the combined steam demand of the sugar mill and the ethanol generation process exceeded the steam generated. This penalized the electricity generated by the ethanol-BIGCC scenarios, as electricity was needed internally for heating purposes, at a rate of $2.43 \mathrm{MW}$ and $15.63 \mathrm{MW}$ for the VD/ $\mathrm{BIGCC}$ and CD/BIGCC respectively. Thus, the vacuum distillation scenarios offered a more feasible operating scenario when BIGCC technology was considered, as the lower steam consumption minimized the electricity consumed for heating purposes.

A further comparison of vacuum and conventional distillation shows that the application of vacuum distillation allowed for an extra 1.36 MW of electricity to be available for export (comparing CD/CHPSC and VD/CHPSC). This was because the lower steam demand of the vacuum distillation system on the steam utilities allowed for more steam to expand through the exhaust steam turbine of the condensing extraction steam turbine (CEST). Furthermore, the multi-effect system also relieved the cooling duty of the condenser of the rectifier column, and thus, no further electricity was needed to deliver this cooling duty. So even though there was an additional process electricity requirement for the vacuum pump that actuated the multi-effect distillation, the reduction in utility requirements exceeded the requirement, which then resulted in a net positive electricity export.

The energy efficiencies reported in Table 1 were based on the net export of the bio-energetic products, which is the ethanol sold and the electricity exported to the grid after the mill requirements were accounted for. Generally, ethanol scenarios with BIGCC technology had the greatest net export efficiency, followed by that of the BIGCC-EE, which was comparable to the ethanol-CHPSC scenarios, and the lowest being the CHPSC-EE scenario. The reduction in steam consumption in vacuum distillation when CHPSC and BIGCC technology are used for energy generation is shown to improve the export electricity efficiency by $0.41 \%$ and $3.74 \%$ respectively. The improvement when BIGCC technology was integrated with vacuum distillation is explained by the lower amount of electricity consumed internally for heating purposes. The lowest export energy efficiency was attained by the CHPSC-EE scenario, due to the large amount of exhaust steam still present after the steam demand of the sugar mill was accounted for. The energy contained in this steam is mostly spent to the environment by the surface condenser. If a biomass dryer was used to de-moisture the biomass prior to combustion, as in the case of the CHPSC-EE, then the export efficiency improved by $1.42 \%$ because the steam and electricity generation had improved by $6.14 \%$ and $7.65 \%$ respectively.

In order to assess the benefits of pinch point analysis (PPA), values in Table 1 are compared with the corresponding values in Table 2. Table 2 does not report values for the exclusive electricity scenarios because effective heat integration is implicit in the overall design of these processes. Regarding the CHPSC-EE, the design of Nsaful et al. [41], which is the source model for the CHPSC technology, was already optimized with PPA. As for the BIGCC-EE, PPA confirmed the heat integration strategies that have previously been implemented, such as the cooling of the syngas to heat up air for the gasifier, improving steam generation, and also using the inter-cooler duty of the multistage compressor to improve steam generation [37].

The comparison between Tables 1 and 2 shows that the potential for exporting electricity from the ethanol-BIGCC scenarios are reduced by a margin of 30 to $38 \%$ if PPA is not applied, mainly because the increase in steam demand resulted in more electricity consumed for heating purposes. Thus, the primary advantage of PPA is the reduction of steam and electrical utilities, which then resulted in the net export of more electricity, and the general improvement in the export energy efficiencies by $0.98 \%$ and 3.99\% for ethanol-CHPSC and ethanol-BIGCC scenarios respectively. The effect of PPA on the scenario employing conventional distillation seems more apparent because the vacuum distillation already affected a substantial reduction in utilities by inducing multi-effect distillation.

\section{Economic results}

The six scenarios for the production of electricity from sugarcane residues, either as the only energy product or with coproduction of ethanol from hemicellulose, were compared in terms of the total capital investments (TCI) required (Figure 1), the economic viabilities in terms of internal rates of return (IRR) on the investments (Figure 2), and the financial risk of each investment, based on the Monte Carlo simulation, quantified as the probability of an acceptable return on investment (Figure 3). Figure 1 shows that the highest capital investment was $324.57 \mathrm{mil}-$ lion US\$ for the VD/BIGCC cogeneration scenario, which was also the scenario with the highest energy efficiency. The primary reason for the high capital investment is the costs associated with the integrated BIGCC, as shown by 
Table 2 Yields, utility demands and energy efficiencies without pinch point analysis

\begin{tabular}{|c|c|c|c|c|}
\hline Scenarios & CD/CHPSC & CD/BIGCC & VD/CHPSC & VD/BIGCC \\
\hline \multicolumn{5}{|l|}{ Net Outputs } \\
\hline Bioethanol Production (I/hr) & 9601 & 9577 & 9600 & 9575 \\
\hline Electricity Production (MW) & 18.63 & 52.38 & 20.37 & 52.38 \\
\hline \multicolumn{5}{|l|}{ Steam Generation and Requirements } \\
\hline Gross Steam Generation (tons/hr) & 204.58 & 146.43 & 204.58 & 146.42 \\
\hline Mill Steam Demand (tons/hr) & 120.00 & 120.00 & 120.00 & 120.00 \\
\hline Ethanol Generation Steam Demand (tons/hr) & 68.62 & 68.62 & 49.56 & 49.56 \\
\hline Steam Contingency (tons/hr) & 15.97 & -42.19 & 35.02 & -23.14 \\
\hline As percentage of Total Steam Demand & 8.47 & -22.37 & 20.66 & -13.65 \\
\hline \multicolumn{5}{|l|}{ Electricity Generation and Requirements } \\
\hline Gross Electricity Generation (MW) & 36.63 & 187.50 & 38.99 & 187.51 \\
\hline Power (MW) & 1.01 & 122.63 & 1.21 & 122.63 \\
\hline Ethanol Utilities (MW) & 4.50 & 31.29 & 4.92 & 19.61 \\
\hline Mill Electricity Demand (MW) & 12.49 & 12.49 & 12.49 & 12.49 \\
\hline Net Energy Efficiency & $24.53 \%$ & $34.70 \%$ & $25.05 \%$ & $34.70 \%$ \\
\hline
\end{tabular}

the difference in capital costs between the ethanol scenarios with vacuum distillation that have either the CHPSC or BIGCC technologies integrated as energy islands. The application of the vacuum distillation also demanded higher capital costs, as is shown by the general comparison of the vacuum and conventional distillation scenarios. With VD, additional capital charges were also incurred by the larger capacity of the surface condenser and circulation pumps. This was because of the lower steam demand, which resulted in a greater throughput of steam in the equipment mentioned. Thus, the use of VD is shown to increase the capital expenditure by $9.33 \%$ when CHPSC technology is used, and $4.33 \%$ when the BIGCC technology is used as energy schemes, respectively.

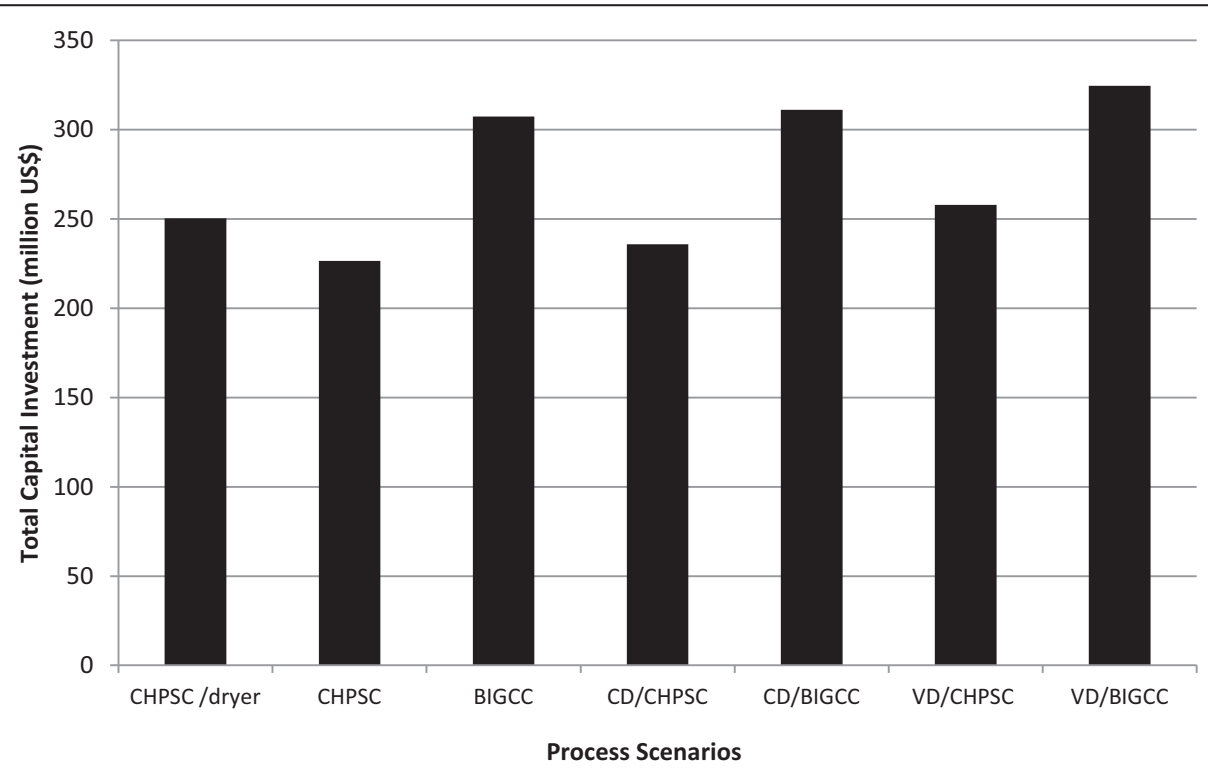

Figure 1 Total capital investment for simulated scenarios. (CD/CHPSC - Ethanol Production with Conventional Distillation with energy generation from pretreatment residues using CHPSC; CD/BIGCC - Ethanol production with Conventional Distillation with energy generation from pretreatment residues using BIGCC; VD/CHPSC - Ethanol Production with Vacuum Distillation with energy generation from pretreatment residues using CHPSC; VD/BIGCC - Ethanol production with Vacuum Distillation with energy generation from pretreatment residues using BIGCC; CHPSC-EE - Exclusive electricity generation from residues using CHPSC; CHPSC-EE (Dryer) - Exclusive electricity generation from residues using CHPSC where biomass is dried; BIGCC-EE - Exclusive electricity generation from residues using BIGCC). 


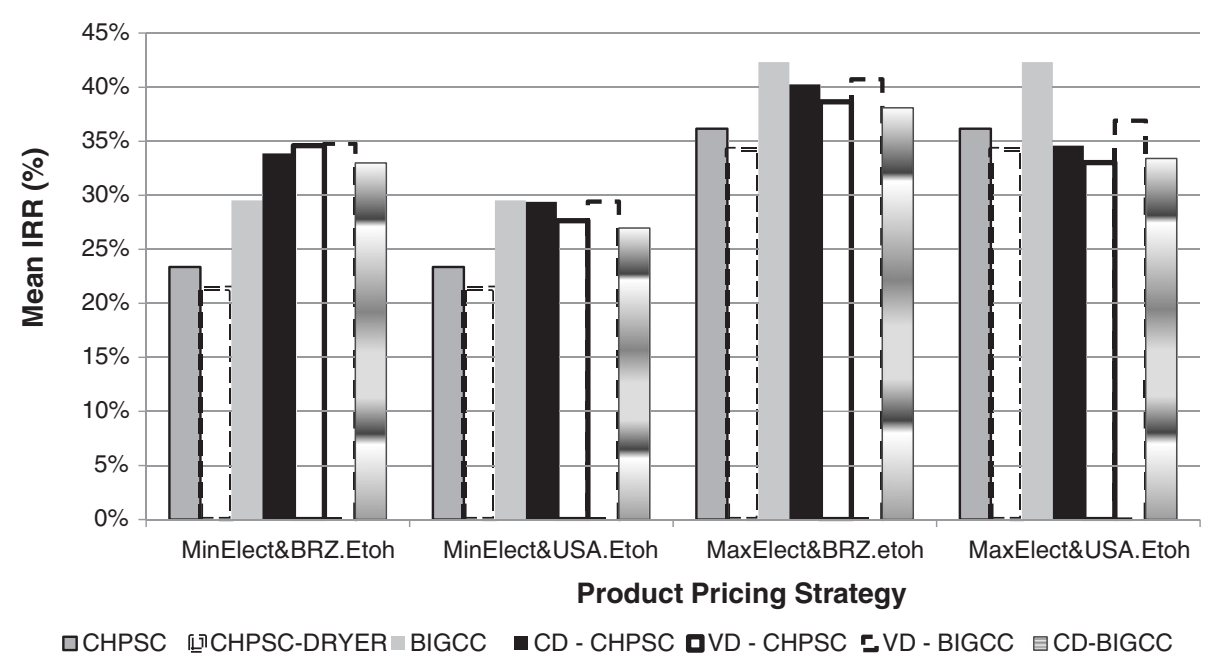

Figure 2 Comparison of processes profitability at varies strategies. "Mean IRR" refers to the average of the IRRs determined from each iteration of the Financial Risk Simulation.

The TCI of BIGCC-EE, which was based on a modern estimate [42], is $28.89 \%$ higher than the average TCI of CHPSC-EE. This difference is much less than those attained in previous comparative studies that based the BIGCC capital estimates on pioneer costs. The relative difference between BIGCC and the CHPSC technologies in Dornburg et al. [43] and Bridgwater et al. [12] was about $50 \%$ and $77 \%$ respectively. The difference in the comparison by Bridgewater et al. [12] had been exceptionally large, since the scale on which the comparison was based was a $20 \mathrm{MWe}$. Trends shown by Bridgewater et al. [12] and Dornburg et al. [43] have indicated that the difference gets smaller as the scale increases.

With regards to exclusive electricity production, it is shown (Figure 2) that the lowest IRRs were attained by the CHPSC-EE scenario, both inclusive and exclusive of the biomass dehydration prior to combustion. The IRRs obtained for the combustion scenarios did not differ significantly from each other, and on average were $22.38 \%$ $( \pm 0.98 \%)$ and $35.20 \%( \pm 0.97 \%)$ at the minimum and maximum premiums on electricity, respectively. In either case, the higher value was obtained when no dryer was considered. Thus, the energy efficiency gained by employing a biomass dryer was not economically justified, due to the increased capital expenditure. The IRR attained by the BIGCC-EE is $7 \%$ and $6 \%$ higher than those attained by the CHPSC-EE scenario, when the minimum and maximum premiums on electricity were considered, respectively. In previous studies where the capital estimates of the BIGCC technology were based on pioneer quotes, the profitability of CHPSC technology was generally higher $[12,43]$. As the capital estimate of the BIGCC technology

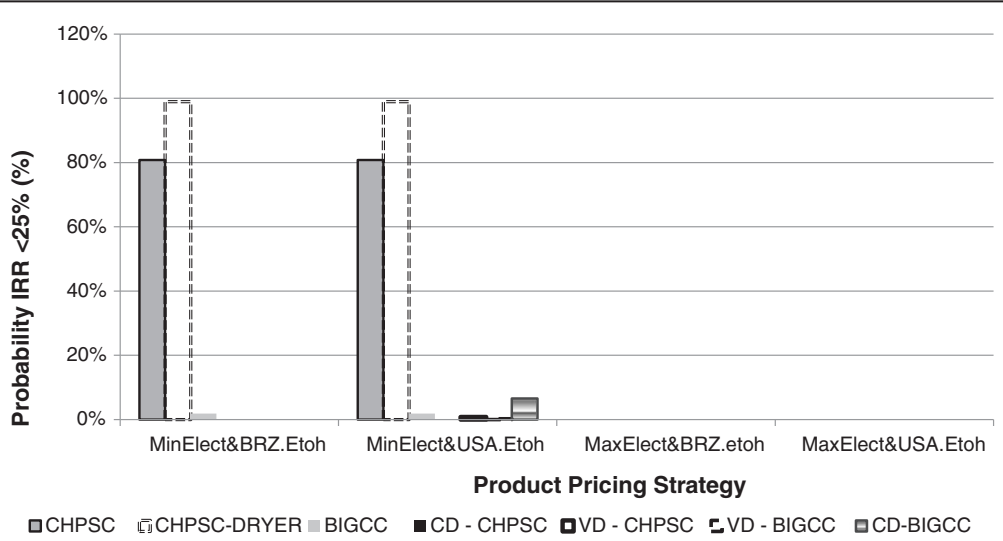

Figure 3 Evaluation of financial risk at varies pricing strategies. The value on the vertical axis describes the probability to which the IRRs simulated for each scenario will fall below a standard value of $25 \%$ for the IRR. 
in this study was based on a modern estimate, it shows that BIGCC-EE became more favorable, which had also been demonstrated by Searcy and Flynn [15].

It was calculated that on average, the ethanol prices projected from Brazilian data were $47 \%$ greater than those based on US data, and therefore the overall minimum pricing strategy was the minimum electricity premium for electricity with US-based ethanol prices. At this pricing scenario, the highest profitability of the ethanol scenarios was attained by the VD/BIGCC. The economic feasibility of integrating BIGCC technology as the heat and power system of ethanol coproduction is advantageous over the CHPSC technology as the profitability of the VD/BIGCC was higher than the VD/ CHPSC. This result was expected since the BIGCC-EE was more profitable than the CHPSC-EE when the exclusive electricity scenarios were compared due to the larger surplus of electricity. With regards to the implementation of VD, the IRR of the VD/CHPSC scenario was $1.05 \%$ lower than that of the CD/CHPSC, whereas the IRR of the VD/BIGCC was $1.48 \%$ higher than the $\mathrm{CD} / \mathrm{BIGCC}$. Thus, VD was not justified by the additional capital costs when integrated with CHPSC technology, but was more profitable when integrated with BIGCC technology. Due to the high amount of electricity that was needed for heating purposes in the $\mathrm{CD} / \mathrm{BIGCC}$ scenario, the IRRs was lower than the VD/BIGCC, even though the capital expenditure was less.

When the maximum electricity premium was considered, the IRR of the BIGCC-EE was 1.59\% higher than the most profitable ethanol scenario (VD/BIGCC) obtained with the higher (Brazilian) ethanol prices. Under the lower (US) ethanol pricing, the BIGCC-EE was 5.44\% higher than the VD/BIGCC scenario (still the most profitable of the ethanol scenarios). Regarding the maximum electrical premium however, the IRRs shown in Figure 2 for exclusive electricity scenarios are well in excess of the standard IRR of $17 \%$ that is imposed by the National Energy Regulator of South Africa (NERSA) for independent power producers (IPPs) [44]. In order to diversify the renewable energy contribution of the South African electricity supply (for example, from solar or wind), the prices paid to IPPs are regulated by NERSA to maintain an IRR of $17 \%$, in order to promote equal investment opportunity in the various forms of renewable electricity [44]. Thus, as both the BIGCC-EE and CHPSC-EE are shown to meet this target at the minimum electricity premium, a higher price for electricity generated in the sugar mills would not be allowed.

With regards to assessing the scenarios from a financial risk perspective (Figure 3), the maximum occurrence at which the IRR can be less than $25 \%$ (which is known to attract the interests of private investors $[36,45]$ ) was a probability of $20 \%$ [ 41 ]. This qualification of $20 \%$ is an extension of a general criterion applied for the maximum probability of the net present value (NPV) being less than zero [41]. At the optimistic pricing scenarios, where high premiums on electricity are considered, all scenarios would be attractive for private investment (Figure 3) when the IRRs are evaluated against the IRR standard of $25 \%$. An evaluation at the minimum pricing scenario showed that all ethanol coproduction scenarios qualified for private investment, since the risks associated with an unfavorable return for private investment were generally less than $1 \%$. The maximum risks were attached to exclusive electricity production involving combustion, as the probabilities of the IRR falling below the standard of $25 \%$ were above $80.82 \%$ for the CHPSC-EE without drying and $98.96 \%$ with drying.

The status of the high risk imposed by the exclusive electricity scenarios to private investment would not improve due to restrictions imposed by NERSA on IPPs in respect of the standard IRR of $17 \%$. However, sensitivity in the ethanol prices could allow for private investment that is virtually risk free when coproduction of ethanol is considered, as shown when ethanol prices are projected from the Brazilian data. Under that circumstance, the risks of an unfeasible return for a private investor for all the ethanol scenarios are acceptable, even when the minimum premium for electricity is considered.

\section{Comparison of the present study with similar studies in published literature}

Since the CHPSC-EE scenario was modelled on the flow sheet of Nsaful et al. [41], the results of this scenario was validated with the technical and economic results of the scenario using combustion and 82 bar steam cycle, in that study. The export efficiency calculated based on the electrical export of $86.02 \mathrm{~kW}$ per ton of cane amounts to $12.70 \%$, which is lower than the export efficiency of $15.44 \%$ reported for the CHPSC-EE of this study. The export efficiency of this study is higher because the electricity generation was supplemented with sugarcane trash, which improved the amount of electricity available for export. The IRR reported for the process modelled by Nsaful et al. [41] was $29 \%$, when a bagasse and electricity price of 56 US\$/dry ton (data from 2010) and $0.248 \mathrm{U \$}$ per kWhr are considered respectively. Under these conditions, the model in this study yielded an IRR of $41.82 \%$. The optimistic outcome arose because the supplementation by trash improved the export electricity to $170.01 \mathrm{~kW}$ per ton of cane processed. Furthermore, the incorporation of trash, which costs just $30 \%$ of the bagasse price, reduces the average specific cost paid for biomass in the model of this study to $41.53 \mathrm{U} \$$ /dry ton (data from 2010).

The BIGCC-EE scenario was compared with the results of Craig and Mann [46], who conducted a techno- 
economic study of various options for a BIGCC power plant fuelled by wood. Options explored included various gasification scenarios, such as pressurized versus near-atmospheric conditions, and direct versus indirect heating. Since this plant was an autonomous facility, the energy demands of the sugar mill were discarded in order to remodel the BIGCC-EE scenario as an autonomous facility, so that the results could be comparable. The net electrical efficiency of the autonomous BIGCC$\mathrm{EE}$ was $34.2 \%$, which compared well with the value of $37.9 \%$ obtained by Craig and Mann [46]. The efficiency of Craig and Mann [46] is expected to be higher because the combined steam cycle of the pilot plant operated at the much higher pressure of $100 \mathrm{bar}$, which was a more efficient system for the steam cycle than the steam cycle in this study, which operated at a steam pressure of 60 bar. Thus a greater contribution was expected from the steam cycle section in that study [41]. Furthermore, Craig and Mann [46] assumed an efficient design of the gasifier that assured complete conversion of the biomass, whereas this study considered a conservative case where only 90 to $95 \%$ of the biomass was converted.

The minimum electricity price (MEP) determined by Craig and Mann [46] was 0.07 US\$ per kWhr on a currency base of 1996, which is equivalent to a 2012 price of 0.132 US\$ per $\mathrm{kWhr}$. This was attained under the economic constraints of a biomass price of 78.67 US\$ per dry ton (US\$/d-ton) and an IRR of $10 \%$. With such constrains, the exclusive BIGCC-EE of this study was shown to obtain a MEP of 0.10 US\$ per $\mathrm{kW} / \mathrm{hr}$. The discrepancy then arises from the maturity of the capital cost estimates, as Craig and Mann [46] used very early stage estimates of BIGCC systems (1990), which was $51.97 \%$ more than the modern estimate (2008) used in the BIGCC scenarios of this study.

The results of the CD/CHPSC was compared to the feasibility assessment of an integrated ethanol facility conducted by Macrelli et al. [11], where the cellulose fractions of bagasse and trash residues were considered for second generation ethanol production. The net export efficiency of the integrated component, based on the export of electricity and lignocellulosic ethanol generated, was $35.2 \%$, which is significantly higher than the efficiency of $25.57 \%$ determined for the CD/CHPSC. This arose because Macrelli et al. [11] considered the cellulose fraction for ethanol production, which constitutes 35 to $40 \%$ of the considered biomass, as opposed to hemicellulose which only constitutes 20 to $24 \%$ of the considered biomass (see Table 3). Thus, a greater fraction of the biomass was efficiently used for the production of the energetic product.

The MESP (Minimum Ethanol Selling Price) that was determined for the lignocellulosic ethanol by Macrelli et al. [11] was 0.97 US\$ per litre, under the economic constraints of a sugarcane trash price of 26 US\$ per dry ton and an IRR of $10 \%$. This MESP included a penalty of 0.12 US\$ per litre for the reduction of export electricity when compared to electricity exports of an autonomous first generation facility and an enzyme cost of 0.38 US\$ per litre. Thus, the MESP was adjusted to 0.47 US\$ per litre by disregarding the penalty and enzyme cost, for a consistent comparison with this study. Under the economic constraints in the study of Macrelli et al. [11], the CD/CHPSC obtained a MESP of 0.43 US\$ per litre, which compares well with the adjusted MESP of Macrelli et al. [11]. This comparison also shows that although a process converting cellulose to ethanol is more energy efficient, it is less economically viable due to the major cost associated with the enzymes needed to hydrolyse cellulose.

\section{Sensitivity analysis}

Figure 4 and Figure 5 show the economic sensitivity of the economic parameters to certain parameters that were deemed to have an uncertainty in their specification. The sensitivity was carried out with the pricing strategy that considered the minimum selling prices of electricity and ethanol. The coproduction scenarios with the highest profitability were the VD/BIGCC and the $\mathrm{CD} /$ CHPSC, which were also the best indications of advanced and immediate technologies available, respectively. Thus, these scenarios were subjected to sensitivity analysis. Since the CD/BIGCC and VD/CHPSC were not as technically and economically viable, they were not included in the sensitivity analysis.

With regards to the sensitivity of the overall ethanol output on profitability (Figure 4), a yield improvement of $10 \%$ generally increased the measured IRRs by $1.89 \%$, which improved the IRR of the most optimal ethanol scenarios to $31.29 \pm 0.29 \%$. Alternatively, a yield that worsened by $10 \%$ reduced the IRRs by $2.02 \%$ on average to $27.38 \pm 0.39 \%$. The most important observation here is that a reduced yield had only increased the risk of the IRR receding below $25 \%$ by a margin of $5.68 \%$ at most (for the CD/CHPSC). Thus, the most economically viable ethanol scenarios remained desirable for investment from

Table 3 Chemical composition of sugarcane residues

\begin{tabular}{lcc}
\hline Component (\%) & Bagasse $^{\mathbf{1}}$ & Trash $^{\mathbf{2}}$ \\
\hline Cellulose & 41.1 & 39.8 \\
Hemicelluloses & 26.4 & 28.6 \\
Lignin & 21.7 & 22.5 \\
Ash & 4.0 & 2.4 \\
Extractives & 6.8 & 6.7 \\
\hline
\end{tabular}

${ }^{1}$ Average of measurements for South African bagasse $[47,48]$.

${ }^{2}$ Composition taken Oliveira et al, [49]. 


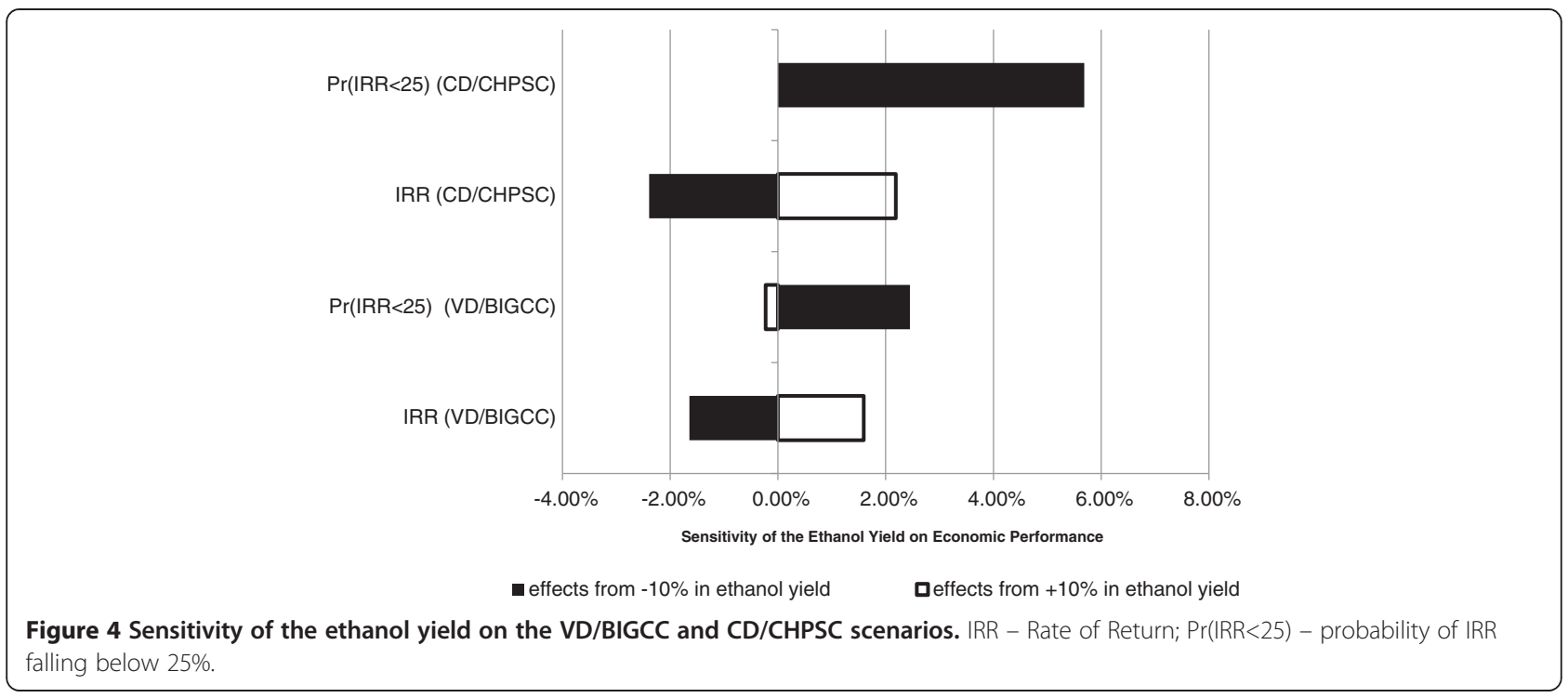

the private sector when suboptimally performing technology was considered.

An increased estimate for the BIGCC installed costs of $10 \%$ (Figure 5) had increased the CAPEX for the BIGCCEE by $10 \%$ and the VD/BIGCC by $7.35 \%$. However, since the VD/BIGCC had the highest CAPEX originally, the effect of an increased installed cost was most prominent on this scenario since its IRR was reduced by a further extent than that of the BIGCC-EE. Given a reduction in the IRR of the BIGCC-EE of $1.31 \%$, it is still far more viable than the CHPSC-EE scenario. Regarding the risk around private investment, the VD/BIGCC is still a viable option, as the probability of the IRR receding $25 \%$ was only $3.10 \%$.

\section{Conclusions}

Ethanol coproduction with electricity generation has been shown to have greater exporting energy efficiency than exclusive electricity generation. This was demonstrated in the context where the status of the electricity generation technologies is advanced, but where the technological status of ethanol production is at a conservative level, considering the modest conversion of sugars to ethanol using the detoxified hydrolysates. If a minimum pricing scenario on the ethanol and electricity products is considered, ethanol coproduction with electricity generation is considerably more profitable than CHPSC power plants, but on par with BIGCC power plants. The advantage of ethanol

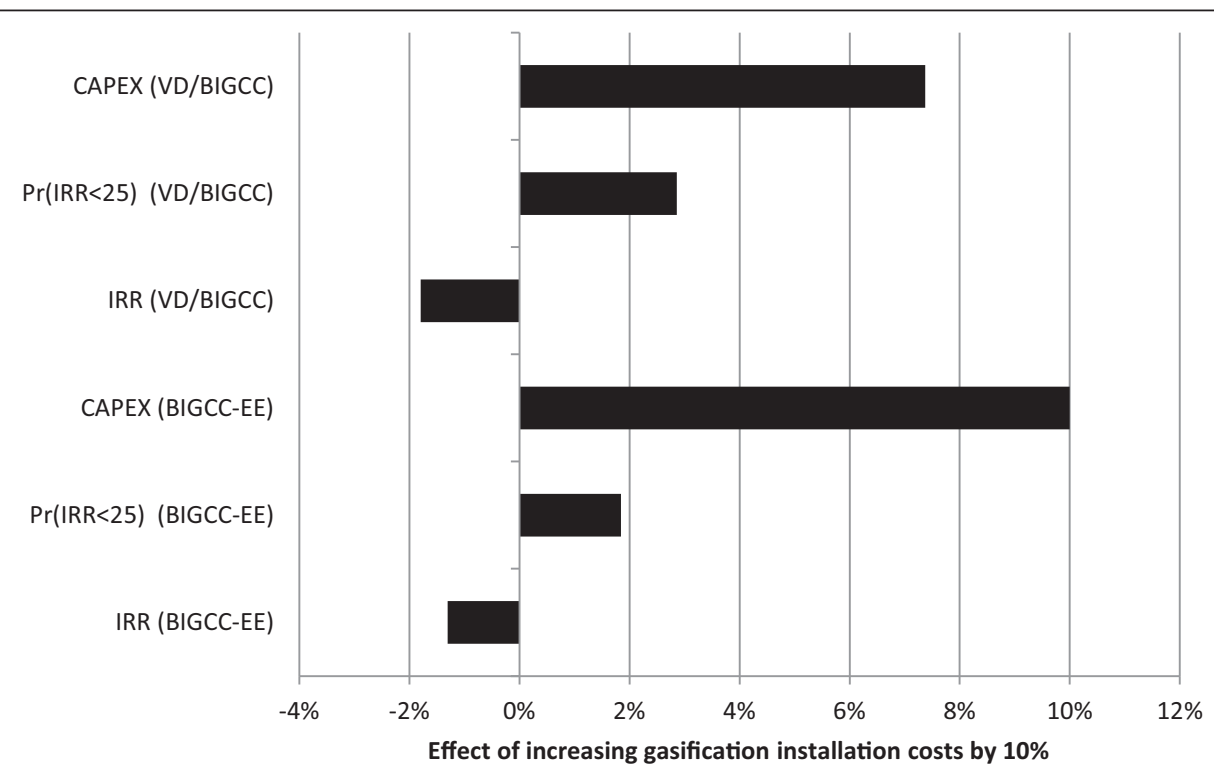

Figure 5 Effect of pessimistic installed estimate of gasification costs on the BIGCC-EE and VD/BIGCC scenarios. IRR - Rate of Return; $\operatorname{Pr}(\operatorname{IRR}<25)$ - probability of IRR falling below 25\%; CAPEX - Capital Expenditure. 
coproduction would become more pronounced as fermentation technology develops and matures as expected, and it would also become attractive for private investment. If the fermentation of hemicellulose hydrolysates (though successful on a bench-scale) can demonstrate that a pilotscale conversion of at least $82.5 \%$ sugar to ethanol can be attained, it will confirm the technology proposed.

While a high premium on electricity would promote exclusive electricity production when ethanol prices are at a minimum, it is not likely that these premiums on electricity would be attained under the current regulations for renewable electricity in South Africa. The reason is because even at lower premiums, the IRR of the BIGCC-EE was $30 \%$, whereas the prices of electricity for IPPs are regulated to allow for a maximum IRR of $17 \%$.

The study showed that at the current scale, additional capital investments for more energy efficient technology is only justified when it effects a significant improvement in energy efficiency, as shown when BIGCC technology is used instead of the direct combustion in the ethanol coproduction schemes. Furthermore, it was found that when a more energy efficient technology only effected a minor improvement in energy efficiency, such as VD applied in the ethanol coproduction process or biomass dehydration in a combustion process, the economic returns did not justify the capital investment. There would be situations however, where the energy intensity of the process would demand the implementation of such measures, either to reduce process steam demand or improve steam generation to a feasible operating range.

\section{Methods}

\section{Basis for simulation and assumptions}

All of the scenarios analyzed in the present study assume that the steam demand of the sugar mill itself will be 0.4 tons per ton of cane processed The capital investments required to upgrade existing sugar mills in South Africa to achieve this level of energy efficiency has been estimated at US\$ 17.32 million [3,50] (in 2012) for a 300 ton per hour crushing rate. The technical measures included the optimisation of imbibitions rate to reduce the amount of evaporation needed [50]; the conversion from the batch pans to continuous pans and reduce the pan movement water $[3,9,50]$; using a five-effect evaporator where vapour is bled to the vacuum pans at a lower effect [9]; optimisation of the flashing of condensates for steam recovery [50] and finally; electrifying the turbine drivers [3,4].

The cane crushing capacities of mills in South Africa range from 190 to 600 tons per hour [51,52], and thus the representative average of 300 tons per hour was assumed for the present study. Based on a fibre content of $0.14 \mathrm{~kg} / \mathrm{kg}$ of cane [5], 42 tons per hour of bagasse would be generated from the cane crushing activities for energy generation. Of the total harvesting residues, amounting to $1.167 \mathrm{~kg}$ per $\mathrm{kg}$ of bagasse [53], 50\% of this amount would be collected and co-fed with all the bagasse into an 'energy island' in the mill to generate the energy requirements of the mill (40\% steam on cane [41] and $41.64 \mathrm{kWe}$ [4] per ton of cane) and the export energy products. The composition of the residues is shown in Table 3.

\section{Process technology considerations \\ Exclusive electricity generation from lignocellulosic biomass}

Nsaful et al. [41] developed a flow sheet for the conversion of bagasse from a sugarcane milling operation to steam and electricity with a high pressure steam system using combustion (Figure 6). They found that the optimum boiler pressure for efficient electricity generation was 82 bar. Based on the net amount of export electricity, the electrical generation efficiency was $21.5 \%$ for 82 bar and $20 \%$ for 63 bar. Conversations with experts in the South African sugar industry indicate that the design pressure for boilers which will be used to retrofit the sugar mills is 86 bar. Consequently, a boiler pressure of 86 bar is assumed in this study. Conventionally, biomass would enter the combustor at about $45 \%$ moisture, though it could also be dried with flue gas to improve the boiler efficiency, with additional capital charges. The minimum acceptable moisture content for bagasse is $30 \%$, so as to avoid self-ignition and/or a dust explosion [54]. Excess air is provided to the boiler, which has been preheated to $250^{\circ} \mathrm{C}$ [41] by the stack gas, to improve the overall efficiency. The amount of air in excess is determined to ensure a minimum oxygen content of $6 \%$ in the flue gas, as per environmental regulations [55].

The boiler would generate superheated steam at about $515^{\circ} \mathrm{C}[10]$ and 86 bar that would be expanded in a CEST to generate electricity. The intermediate pressures in the CEST are 13 and 4 bar, and the final vacuum pressure is 0.2 bar [56]. The vacuum steam would then be condensed and returned to the steam cycle. Steam for the mill would be extracted from the CEST at 4 bar. Regarding the performance of the turbines, the isentropic efficiency was $85 \%$ while the combined mechanical and electrical efficiencies were set at $96.06 \%$ (i.e. $98 \%$ for electrical and $98 \%$ for mechanical [57]).

The general flow sheet of the BIGCC system (Figure 7) for biomass conversion to electricity was adapted from models developed by the NREL $[46,58]$ and previous reports [59-61]. The combined bagasse and trash would be initially dried to a moisture content of 10 to $15 \%$ with exhaust flue gasses $[59,60]$. The moisture content within the biomass would serve as the gasification control agent [59] since steam injection is generally not considered for gasifier applications in the BIGCC systems. The amount of air added to the circulating fluidized bed (CFB) gasifier in the BIGCC system is to ensure the highest possible 


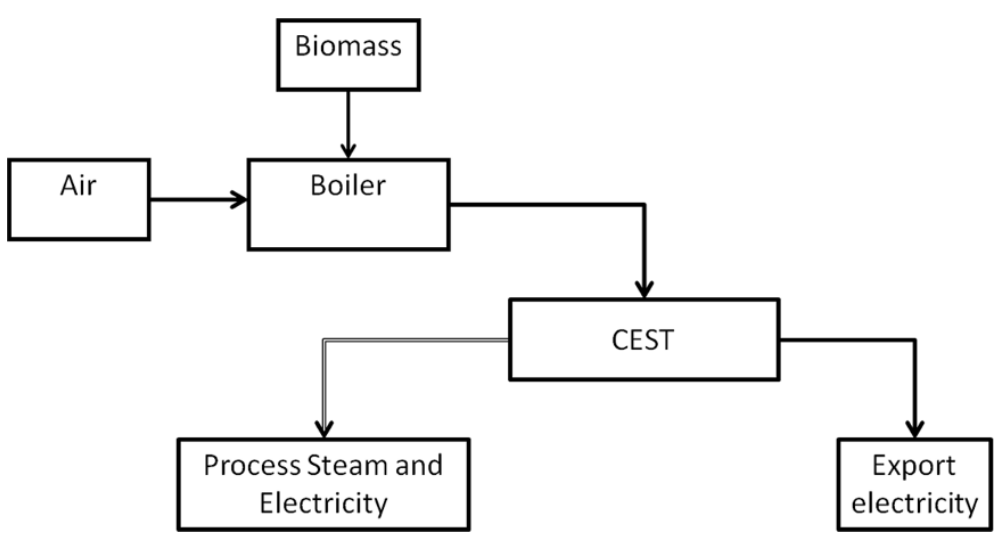

Figure 6 Combustion with High Pressure Steam cycles (CHPSC) flow sheet. (CEST - Condensing Extraction Steam.

calorific value of the syngas without an excess of tars. To initiate tar cracking, the gasifier is required to be operated at $800^{\circ} \mathrm{C}$. This is achievable when the ratio of the air supplied to the stoichiometric amount for complete combustion (equivalence ratio) is 0.25 to 0.3 [59]. The syngas would then enter a cyclone to remove particulate matter before entering the CFB tar cracker, where additional air is added to increase the temperature to $920^{\circ} \mathrm{C}$ [46] for cracking to occur with a dolomite catalyst [46].

After tar cracking, the temperature of the syngas would be reduced to $288^{\circ} \mathrm{C}$ in order to condense the alkali species for removal with any other particulate matter in a filter bag [46]. The syngas is further cooled to $97^{\circ} \mathrm{C}$

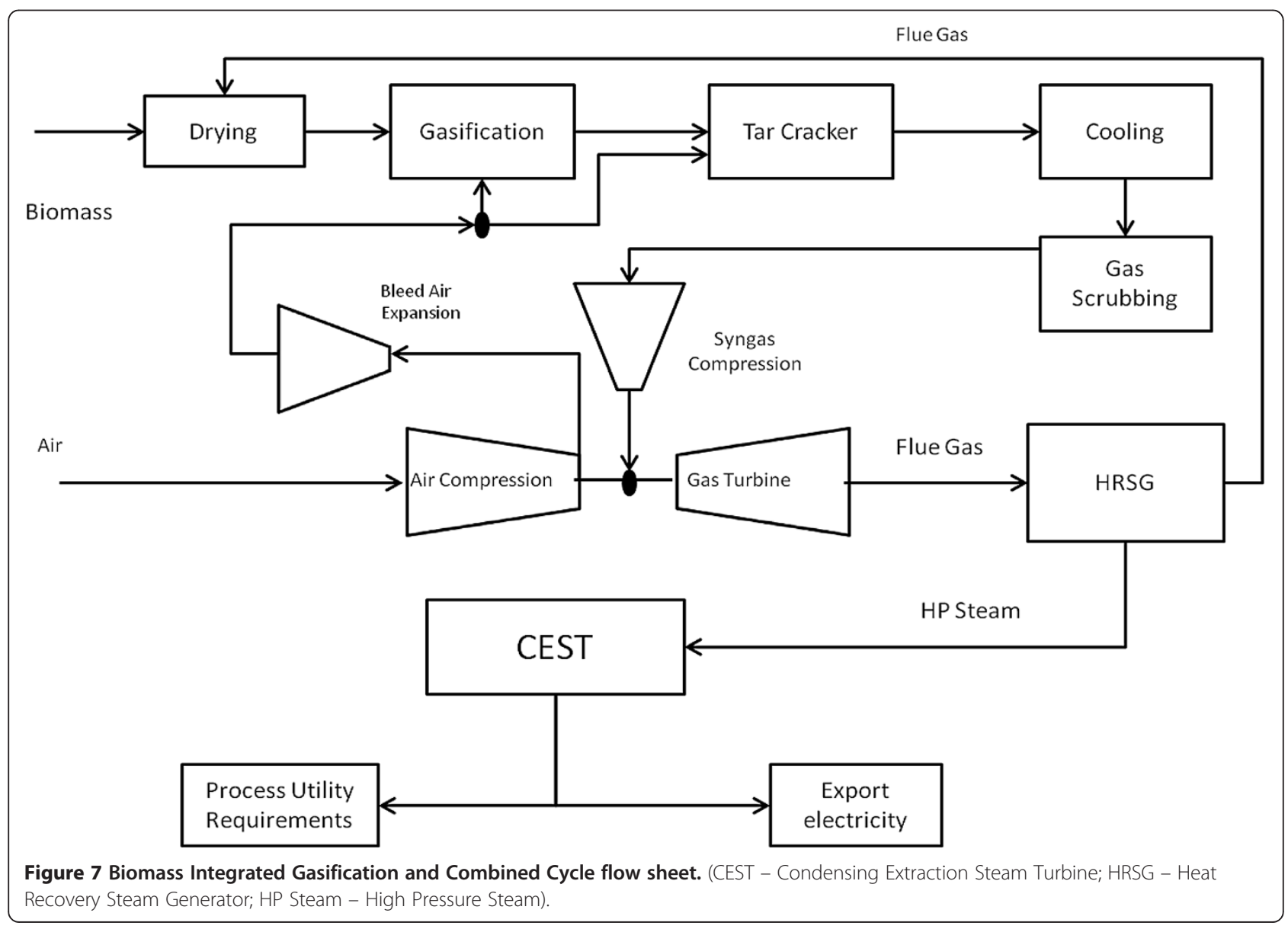


before it is scrubbed with water to remove the nitrogenous and sulfurous compounds for the protection of downstream equipment, and to prevent nitrous and sulfurous oxide emissions $[46,60]$. The scrubbing also humidifies the syngas, which assists in the control of the temperature in the gas turbine [62].

The syngas is compressed in a multi-stage compressor (two compressors with an inter-stage cooler in-between) to $20 \mathrm{bar}$, which is 4 bar above the combustion pressure of the gas turbine [63], in order to allow for the pressure drop across the feed nozzle [61]. At the inter-stage cooler, the syngas was cooled to $97^{\circ} \mathrm{C}$ at an intermediate pressure of 6 bar, which was determined by the optimization procedure of Polyzakis et al. [63]. The air required for the gas turbine would be compressed in the compressor chamber of the gas turbine, and is fed at a mass ratio of 1:5.14 to the syngas [64]. In order to compensate for the extra volumes of dilution gasses in the syngas that is not found in natural gas, such as $\mathrm{CO}_{2}$ and nitrogen, air would be bled from the compressor chamber before the air enters the combustion chamber $[46,60,64]$ since the gas turbines are designed for natural gas which does not contain inert gasses. The rate at which air is bled amounts to $13.3 \%$ of the air fed to the compression chamber, which is in excess of the air demands of the gasifier and cracker. The bleed air would be expanded through a turbine to atmospheric pressure to improve the net electricity output [60]. Once expanded, the air would be preheated to the gasifier temperature to be used to feed the gasifier and tar cracker. Regarding the efficiency of the gas turbine, the compressor section has a polytrophic efficiency of $0.87 \%$ and the gas turbine has an isentropic efficiency of $89.77 \%$ [57]. The mechanical and electrical efficiencies are both set at 98\% [57].

The combustion exhaust gas leaves the combustion chamber at about $1100^{\circ} \mathrm{C}$ and is expanded to 1 bar in the turbine section to generate the bulk of the electrical output by driving the generator. The heat of exhaust gasses of the turbine is captured in a HRSG to generate steam at $60 \mathrm{bar}$ for the 'combined' steam cycle $[58,60,61]$. The superheated steam is generated with water that had been preheated with waste heats from the BIGCC system, as determined by PPA. The superheated steam is then expanded in a CEST to provide the steam demands and additional electricity. The exhaust gas of the HRSG has a temperature of $200^{\circ} \mathrm{C}$ and is used to dry the biomass that entered the BIGCC system [60].

\section{Ethanol coproduction from hemicellulose}

A general overview of the process flow sheet for the coproduction of ethanol and electricity is presented in Figure 8. Regarding the process step for pretreating the biomass for hemicellulose solubilization, the two methods that have been established for this purpose are dilute acid hydrolysis (DAH) and steam explosion (STEX). As shown in Table 4, the DAH process typically provided a lower yield of hemicellulose sugars than the STEX and only operated effectively at solid contents of $20 \%$ and below. STEX had been shown to operate effectively at $50 \%$ (Table 5 ), which implies that the energy requirements for DAH were much higher due to the large volumes of water to be evaporated to concentrate the hydrolysate for efficient downstream processing $[47,65]$. Thus, STEX was selected as the

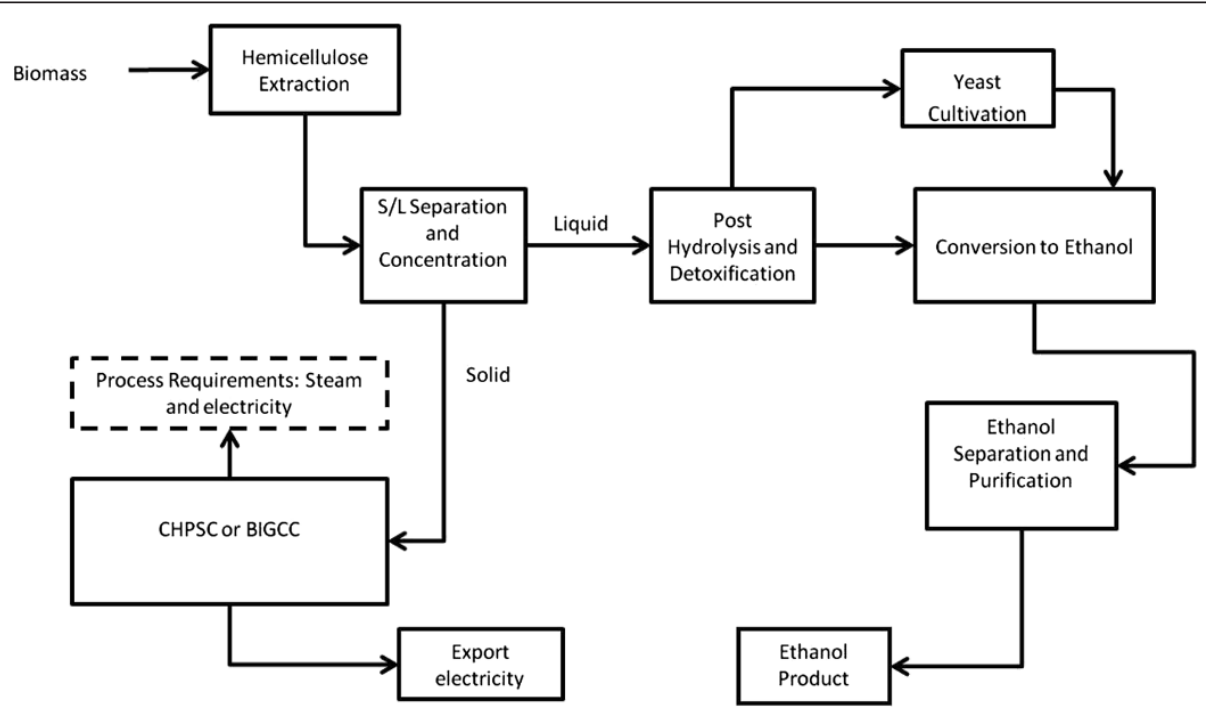

Figure 8 Ethanol coproduction flow sheet. (BIGCC - Biomass Integrated Gasification and Combined Cycles system; CHPSC - Combustion with High Pressure Steam Cycle; S/L Separation - Solid Liquid Separation. 
Table 4 Comparison of hemicellulose solubilization techniques (WIS - Water insoluble solids)

\begin{tabular}{|c|c|c|c|c|}
\hline \multicolumn{5}{|l|}{ Dilute acid hydrolysis } \\
\hline & Hemicellulose & WIS & Solubilisation & Yield \\
\hline & $\%$ & $\%$ & $\%$ & $\mathrm{~g} / 100 \mathrm{~g}$ \\
\hline Aguilar et al. [67] & 21 & 10 & 92 & 19.0 \\
\hline Canilha et al. [19] & 26 & - & 62 & 15.9 \\
\hline Tricket [68] & 30 & 19 & 71 & 21.3 \\
\hline Diedericks et al. [48] & 24 & 30 & 75 & 18 \\
\hline Lavarack et al. [69] & 28 & 20 & 72 & 20.0 \\
\hline \multicolumn{5}{|l|}{ Steam Explosion } \\
\hline & Hemicellulose & WIS & Solubilisation & Yield \\
\hline & $\%$ & $\%$ & $\%$ & $g / 100 \mathrm{~g}$ \\
\hline Rudolf et al. [26] $\left(\mathrm{SO}_{2}\right.$ catalysed) & 26 & 50 & 87 & 23 \\
\hline Carrasco et al. [70] ( $\mathrm{SO}_{2}$ catalysed) & 24 & 50 & 57 & 16 \\
\hline Ferreira-Leitao et al. [71] $\left(\mathrm{CO}_{2}\right.$ catalysed $)$ & 23 & 50 & 63 & 14 \\
\hline Laser et al. [72] (uncatalysed) & 26 & 50 & 91 & 24 \\
\hline Rocha et al. [73] (uncatalysed) & 25 & 50 & 82 & 21 \\
\hline Oliveira et al. [49] (uncatalysed) (trash) & 29 & 15 & 93 & 27 \\
\hline
\end{tabular}

technology for hemicellulose solubilization. After pretreatment, the pretreated slurry is washed and filtered to recover the solubilized sugars as a filtrate from the solid residue (containing the cellulose and lignin fractions) that is converted to heat and power (via CHPSC or BIGCC). The sugar recovery to the filtrate was conservatively estimated at $80 \%$, even though recoveries as high as $91 \%$ have been reported in the literature [21]. Regarding the gasification of residue from steam explosion, it produces a syngas with a higher calorific value than that produced from raw biomass, but the gasifier must be slightly bigger, to accommodate the lower reactivity of the pretreated biomass [66].

STEX without catalysis requires a secondary hydrolysis of the hydrolysate to convert the oligomers to fermentable monomeric sugars [76] by treatment with sulfuric acid at a level of $0.5 \%$ (wt) in solution at $120^{\circ} \mathrm{C}$ for 20

Table 5 Fermentation parameters

\begin{tabular}{ll}
\hline Parameter & Value and description \\
\hline Hydrolysate & Alkaline detoxification [24,25] \\
$\begin{array}{l}\text { Total dissolved sugars in } \\
\text { raw hydrolysate }\end{array}$ & $\begin{array}{l}200 \mathrm{~g} / \mathrm{l} \text { primarily consisting of } \\
\text { hemicelluloses. Glucose originating from } \\
30 \% \text { solubilisation of the cellulose in the } \\
\text { trash [49] }\end{array}$ \\
Fermentation Mode & $\begin{array}{l}\text { Fed-batch, initially with } 60 \% \text { of the reactor } \\
\text { loaded with diluted hydrolysate }\end{array}$ \\
Fed-Batch Initial Sugars & $\begin{array}{l}92 \mathrm{~g} / \mathrm{l}, \text { as per the hydrolysate in Kurian et al. } \\
{[24]}\end{array}$ \\
Yeast loading & $1.5-2 \mathrm{~g} / \mathrm{l}$ dry weight [25,74] \\
Conversion to Ethanol & $82.5 \%$ of pentose, $90 \%$ of hexose \\
Fermentation Time & 140 hours [75]
\end{tabular}

minutes [76]. This two-step process is advantageous over the catalyzed STEX (and DAH) because catalysis is intended for improving enzymatic digestibility (which is of no significance in this study) rather than the solubilisation of hemicellulose [77]. Furthermore, the yield of solubilisation with no catalysis is less variable, as shown in Table 6 and lastly, the costs of purchasing or producing $\mathrm{SO}_{2}$ and effective impregnation equipment are avoided.

The theoretical conversion of hemicellulose of the mixed biomass is assumed as $88 \%$, which is the weighted average obtained with bagasse [72,73] and trash [49] (at a feed ratio of $1: 0.583)$ at temperatures ranging from 200 to $210^{\circ} \mathrm{C}$ with a STEX time of 10 minutes. At such conditions the formation of degradation compounds is significant enough to inhibit the fermentation organisms [72], and thus the neutralization of these compounds by detoxification is necessary. The mode of detoxification would be alkaline treatment $[24,25,28]$ at temperatures below $30^{\circ} \mathrm{C}$ so that no sugar loss occurs [79]. While detoxification has been criticized as an unnecessary economic hurdle in previous process evaluations, it has been shown experimentally that detoxification improves the yield of fermentation by 20 to $25 \%$, even if inhibitor resistant strains are used $[25,80]$. In this study, ammonium hydroxide will be used to carry out detoxification [81] in order to avoid the environmental and operational issues associated with over-liming. The yield of ethanol on sugar and other fermentation parameters for the present study are presented in Table 5, which are conservatively assumed based on previous performances in literature $[26,27]$. To ensure this yield, fed-batch fermentation is adopted, since this mode of fermentation can be 1.5 
Table 6 Economic parameters

\begin{tabular}{ll}
\hline Parameter & Description \\
\hline Plant Life [47] & $\begin{array}{l}\text { 25 years, with 9 operational months per year. } \\
\text { The salvaging value is 20\%. }\end{array}$ \\
$\begin{array}{ll}\text { Period of Economic } \\
\text { Analysis [37] }\end{array}$ & $\begin{array}{l}20 \text { years } \\
\text { Depreciation [37,47] }\end{array}$ \\
$\begin{array}{l}\text { Straight line to salvaging value. } \\
\text { Tax [78] }\end{array}$ & $\begin{array}{l}\text { South African company tax of 28\% } \\
\text { Working Capital [47] }\end{array}$ \\
Other & $\begin{array}{l}\text { To simplify the analysis, an equity of 100\% was } \\
\text { assumed [28,47]. It was further assumed that } \\
\text { capital will be fully paid after construction. }\end{array}$
\end{tabular}

times more efficient than batch fermentation [82]. With regards to the hexose sugars, which resulted primarily from the cellulose content of the sugarcane trash, the conversion will be assumed as $90 \%$ since the yeasts consume these sugars at a much faster rate than the pentose sugars [25].

After fermentation, the beer product is purified in the refining section to produce anhydrous ethanol. The beer is initially flashed at $86^{\circ} \mathrm{C}$ and 0.83 bar to remove the carbon dioxide $\left(\mathrm{CO}_{2}\right)$, and the flash gas enters a knockout drum at 1.1 bar to condense ethanol that has evaporated $[47,65,83]$. The gas from the knockout drum is then combined with the fermentation vent stream and enters a scrubber to ensure the maximum recovery of ethanol $[47,65,83]$. The effluents from the scrubber and knockout drum are combined with the beer stream from the initial flash and fed to the beer column, which produces a vapor phlegm [29] that contains ethanol at 40 to $50 \%$. The phlegm is then fed to a rectifier column that produces hydrous ethanol phlegm of $91 \%$ [83]. The hydrous ethanol phlegm is dehydrated by molecular sieves to produce ultra-pure ethanol product of $99.7 \%[47,65,83]$.

In a variation of the configuration described, the beer column can operate at a vacuum pressure of $0.2 \mathrm{bar}$, which allows for the heat required by the reboiler of beer column to be supplied by the condenser of the rectifier. Dias et al. [29] had shown through pinch-point heat integration that the steam demand of the refining section of an ethanol distillery can be significantly reduced if such a strategy is employed. This variant would, however, require a vacuum pump to actuate, which implies that the economic impacts of the lower steam demand would need weighing-up with the higher electricity and capital requirement.

\section{Scenario development and simulation Development of scenarios}

For electricity and steam generation, technological variants included biomass integrated gasification with combined cycles (BIGCC) and combustion with high pressure steam cycles (CHPSC). Regarding ethanol purification, the technological variants included conventional distillation (CD) and vacuum distillation (VD). Therefore, from these process technologies, the alternative process scenarios that were modelled as all possible combinations of the process options included BIGCC exclusive electricity generation (BIGCC-EE); CHPSC exclusive electricity generation (CHPSC-EE); CD/BIGCC for coproduction of ethanol and electricity; CD/CHPSC for coproduction of ethanol and electricity; VD/BIGCC for coproduction of ethanol and electricity and VD/CHPSC for coproduction of ethanol and electricity.

\section{Technical simulation}

The simulation of all scenarios were completed in Aspen Plus $^{\circ}$ (Aspen Technology, Inc., Massachusetts, USA) [84] by modelling the flow sheets with the relevant design parameters discussed in the section dealing with process technology considerations. Reactors were simulated as the stoichiometric reactor 'RSTOIC' using conversions evaluated from available experimental data $[28,37,47,65]$. The gasifier in the BIGCC scenarios was modelled as a combination of an adiabatic combustor and equilibrium reactor that determines that determines the gas composition by minimizing the Gibbs Free Energy 'RGIBBS', since the composition of the syngas is close to the equilibrium values $[46,59,85,86]$. Regarding thermodynamic properties, the Non-Random Two-Liquid model (NRLT) for electrolyte systems (ELECNRTL) was used whenever there were electrolytes to consider, and the NRLT was used to model the separation systems $[29,47]$.

The utility requirements were determined with PPA, by importing heat duties of streams and flash drums determined by the Aspen Plus ${ }^{\oplus}$ simulations into the IChemE pinch analysis spreadsheet [87] which were used to calculate the hot and cold utilities according to the methods of Kemp [31] and March [32]. After the utility requirements were taken into account, the net export efficiency ( $\eta$ ) was calculated as the combination of the net export of electricity $\left(E_{n e t}\right)$ and calorific value of the ethanol fuel $(F)$ relative to the calorific input of the biomass ( $\mathrm{m}^{*} \mathrm{HHV}_{\text {biomass }}$ ), as shown in Equation 1 (the standard unit used for these energy quantities was $\mathrm{MJ} / \mathrm{hr}$ ).

$$
\eta=\frac{E_{\text {net }}+F}{m \times H H V_{\text {biomass }}}
$$

\section{Financial risk assessment Method and assumptions}

Results from the process models were used in the economic evaluation models for each of the scenarios considered, in accordance with established process evaluation techniques [88]. The information emanating from these 
Table 7 Static nominal economic expenses

\begin{tabular}{llr}
\hline Item & Cost basis** & Value \\
\hline Maintenance and Repair [78] & US\$/litre & 0.004 \\
Labour Ethanol plant [78] & US\$/litre & 0.016 \\
Management and Quality Control [78] & US\$/litre & 0.005 \\
Real Estate Taxes [78] & US\$/litre & 0.001 \\
Licenses, Fees and Insurance [78] & US\$/litre & 0.001 \\
Miscellaneous Expenses [78] & US\$/litre & 0.005 \\
Total Chemical Cost (per annum) & US\$ & $2,850,292$ \\
CHPSC Operating Costs [42] & US\$/litre & 0.007 \\
BIGCC Operating Costs [42] & US\$/litre & 0.013 \\
Trash Price [7] & US\$/dry ton & 20.44 \\
Bagasse Price & US\$/dry ton & 6.3 \\
\hline
\end{tabular}

**All prices are given for the year 2012 in the South African Market

${ }^{1}$ Amortized cost for upgrading a South African mill to $40 \%$ steam on cane for liberating bagasse.

models were used to calculate the key economic variable (KEI), namely, IRR [88]. A Monte Carlo simulation was super-imposed on the financial evaluation models in order to create a financial risk assessment whereby the input of certain economic variables into the financial statements would be based on probabilistic distributions that are determined by historical data. This process is then repeated for a large number of iterations and the KEIs generated from the iterations are stored for aggregation in a statistical assessment. The methods followed for these simulations have been described in detail by Richardson et al. $[34,35,78]$ and by the authors of the current study $[36,37]$. The software used for carrying out the simulation was the Simetar Risk Analysis Software (Simetar, Inc., Texas, USA) [89]. The economic parameters that define a South African context under which the financial risk of all processing scenarios were evaluated are given in Table 6.

\section{Capital cost estimates}

The capital costs of generic equipment such as pumps, process drums and turbines were estimated with the Aspen Icarus ${ }^{\circ}$ (Aspen Technology, Inc., Massachusetts, USA) estimator. For all the major or specialized equipment in the ethanol process model, the costs were based on vendor and literature based quotes, such as those in Humbird et al. [74] for steam explosion, hydrolysis equipment and filter presses; Aden et al. [28] for detoxification equipment, cooling water mains pump and cooling tower system; Bailey [90] for surface condensers; Ridgway [91] for vacuum pump; Al-Riyami et al. [92] for heat exchanger costs and finally, Craig and Mann [46] for flue gas biomass dryer.

The cost of the high pressure boiler systems was provided by experts in the South African sugar industry. However, for the BIGCC it was seen that capital estimates tended to be based on whole plant costs in the literature $[16,93]$. Many of these estimates could be traced to vendor quotes from the period when the costs of BIGCC systems were still pioneer costs $[13,16,93]$. Therefore, the most relevant estimate was found in the representative costs in the Report on Combined Heat and Power, of the Environmental Protection Agency of the USA (EPA CHP) [42], which was based on vendor quotes of modern equipment costs.

\section{Nominal economic variables}

In this study, nominal economic variables' refers to specific prices and indices that form the basis of operating costs, incomes and interest-based transactions. These specific values were either determined from the literature or from published databases and are listed in Tables 7 and 8. The variables are treated as 'static' variables (Table 7), which means that the basic prices in year one of the assessment was taken as an average value estimates and

Table 8 Database for stochastic variables

\begin{tabular}{|c|c|c|c|c|c|}
\hline & Electricity [94] & Brazilian ethanol [95] & USA ethanol $[96,97]$ & PPI [98] & Interest rate [99] \\
\hline Unit & US\$ per kWhr & US\$/litre & US\$/litre & & $\%$ \\
\hline 2003 & 0.032 & 0.252 & 0.337 & 124.80 & 15.16 \\
\hline 2004 & 0.039 & 0.254 & 0.422 & 127.70 & 11.31 \\
\hline 2005 & 0.044 & 0.375 & 0.463 & 132.40 & 10.64 \\
\hline 2006 & 0.048 & 0.508 & 0.674 & 142.60 & 11.14 \\
\hline 2007 & 0.040 & 0.467 & 0.524 & 158.20 & 13.08 \\
\hline 2008 & 0.040 & 0.520 & 0.587 & 180.80 & 15.12 \\
\hline 2009 & 0.045 & 0.450 & 0.449 & 180.70 & 11.80 \\
\hline 2010 & 0.054 & 0.612 & 0.483 & 191.60 & 9.91 \\
\hline 2011 & 0.087 & 0.867 & 0.683 & 207.60 & 9.00 \\
\hline 2012 & 0.106 & 0.666 & 0.611 & 220.50 & 8.78 \\
\hline
\end{tabular}


inflated with the projected Producers Purchases Index (PPI) to predict the future value. The 'stochastic' variables (Table 8) were used to generate a multivariate empirical function, from which the future values were iteratively projected for each year in the evaluation in the Monte Carlo simulation.

Regarding the price of second generation ethanol, uncertainty exists because the current pricing of the South African biofuel strategy does not explicitly include second generation fuels [100]. Thus, the price of ethanol was either based on data given for ethanol prices in the USA, or based on data describing Brazilian (BRZ) ethanol prices. Given the uncertainty in the selling price of the export electricity, an upper and lower premium was calculated and applied on the base electricity prices projected from the probability distribution. These premiums were calculated on the minimum and maximum prices for renewable electricity of the South African Renewable Energy bids, which had 2012 based prices of 0.113 and 0.175 US\$ per $\mathrm{kW} / \mathrm{hr}$ respectively [101]. Since biomass based energy is continuous and supplies energy for peak hours, a bonus price of two times the renewable energy price is allowed for four hours per day [101], which thus raises the average renewable prices to 0.139 and 0.216 US\$ per $\mathrm{kW} / \mathrm{hr}$. Relative to the base electricity price (2012 price) in Table 8 , the upper and lower premiums amount to $31 \%$ and $103 \%$ respectively.

With the two possible renewable electricity premiums and two sets of ethanol price data, there would be four possible pricing strategies. Each strategy is considered as a set of parameters under which separate sets of stochastic evaluations of the process scenarios will be conducted. These four pricing strategies are: 1) minimum electricity premium and ethanol prices based on Brazilian data, 2) minimum electricity premium and ethanol prices based on USA data, 3) maximum electricity premium and ethanol prices based on Brazilian data, and 4) maximum electricity premium and ethanol prices based on USA data.

\section{Sensitivity analysis}

The modern capital estimates of BIGCC carry some uncertainty, in that they might be too optimistic. Thus, in order to account for the possibility of a more pessimistic capital estimate, the capital estimates of the BIGCC power plant equipment was increased by $10 \%$, prior to factoring in balance of plant costs (BOP) and project contingencies. Accordingly, a separate stochastic simulation of the BIGCC-EE, CD/BIGCC and VD/BIGCC scenarios was carried out to evaluate the impact of the pessimistic capital estimate.

There is also uncertainty in the yield of ethanol from the hydrolysate, as a very sophisticated organism could yield more ethanol without the need for detoxification, hence negating the associated costs. Furthermore, it is also possible that suboptimal hemicellulose extraction could result in a loss of ethanol. Thus, two sensitivity scenarios of the most profitable coproduction scenarios were simulated. They include: (1) where the overall ethanol yield is decreased by $10 \%$ to account for the suboptimal hemicellulose extraction, and (2) where the overall ethanol yield is increased by $10 \%$ to account for a possibility of a sophisticated fermenting organism which will further discard the costs associated with detoxification. Accordingly, the economic sensitivity to these variations in process parameters was determined using separate stochastic evaluations.

\section{Abbreviations}

BIGCC: Biomass Integrated Gasification and Combined Cycle; BOP: Balance of Plant; BRZ: Brazil; CD: Conventional Distillation; CEST: Condensing Extraction Steam Turbine; CFB: Circulating Fluidized Bed Reactor; CHPSC: Combustion with High Pressure Steam Cycle; DAH: Dilute Acid Hydrolysis; EE: Exclusive Electricity Production; Enet: Net Export Electricity; F: Ethanol Fuel; HRSG: Heat Recovery Steam Generator; IRR: Internal Rate of Return; KEl: Key Economic Indicator; n: net export efficiency; NPV: Net Present Value; NREL: National Renewable Energy Laboratory; PPA: Pinch Point Analysis; PPI: Producers Purchase Index; SA: South Africa; STEX: Steam Explosion; TCI: Total Capital Investment; TR: Technical Related; USA: United States of America;

VD: Vacuum distillation.

\section{Competing interests}

The authors declare that they have no competing interests.

\section{Authors' contributions}

AMP was the primary investigator into the work. He performed all simulations of the various processes and economic evaluations. He also completed the interpretation of results and was the primary author of the written text. MCA was the internal reviser who checked the paper critically for inconsistencies in the text and structure. He also gave assistance in the structuring of the paper. JFG is the study leader of the research group, reviewed the paper internally and approved the submission from our department. He is also the corresponding author. All authors agree to be accountable for all aspects of the work and will ensure that questions relating to accuracy and integrity be appropriately investigated and resolved. All authors read and approved the final manuscript.

\section{Acknowledgements}

The authors would like to thank Chair of Energy Research at Stellenbosch University, funded by the Department of Science and Technology, for providing financial assistance.

Received: 26 November 2013 Accepted: 20 June 2014

Published: 10 July 2014

\section{References}

1. Mbohwa C, Fukuda S: Electricity from bagasse in Zimbabwe. Biomass and Bioenergy 2003, 25:197-207

2. Dias MOS, Cunha MP, Jesus CDF, Rocha GJM, Geraldo J, Pradella C, Rossell CEV, Maciel R, Bonomi A: Second generation ethanol in Brazil: can it compete with electricity production? Bioresour Technol 2011, 102:8964-8971.

3. Peacock S: Process Design for Optimum Energy Efficiency. Glenashley, South Africa: Tongaat Hullet Sugar, Corporate Head Office; 2008.

4. Venkatesh KS, Roy AS: Development and installation of high pressure boilers for co-generation plant in sugar industries. Smart Grid and Renewable Energy 2010, 1:51-53.

5. Ensinas AV, Nebra SA, Lozano MA, Serra LM: Analysis of process steam demand reduction and electricity generation in sugar and ethanol production from sugarcane. Energy Conversion and Management 2007, 48:2978-2987. 
6. Botha T, Von Blottnitz $\mathrm{H}$ : A comparison of the environmental benefits of bagasse-derived electricity and fuel ethanol on a life-cycle basis. Energy Policy 2006, 34:2654-2661.

7. Dias MOS, Junqueira TL, Cavalett $\mathrm{O}$, Cunha MP, Jesus CDF, Rossell CEV, Maciel R, Bonomi A: Integrated versus stand-alone second generation ethanol production from sugarcane bagasse and trash. Bioresour Technol 2012, 103:152-161.

8. Huang H-J, Ramaswamy S, Al-dajani W, Tschirner U, Cairncross RA: Effect of biomass species and plant size on cellulosic ethanol: a comparative process and economic analysis. Biomass and Bioenergy 2009, 33:234-246.

9. Ogden J, Hochgreb S, Hylton M: Steam economy and cogeneration in cane factories. Intenational Sugar Journal 1990, 92:131-140.

10. Moor B: Modern Sugar Equipment Assisting Cogeneration. In Proceedings of the South African Sugar Technologists' Association (SASTA) Congress. Mount Edgecombe, South Africa: SASTA; 2008:1-13.

11. Macrelli S, Mogensen J, Zacchi G: Techno-economic evaluation of 2nd generation bioethanol production from sugar cane bagasse and leaves integrated with the sugar-based ethanol process. Biotechnol Biofuels 2012, $5: 22$.

12. Bridgwater AV, Toft AJ, Brammer JG: A techno-economic comparison of power production by biomass fast pyrolysis with gasification and combustion. Renew Sustain Energy Rev 2002, 6:181-248.

13. Caputo AC, Palumbo M, PMP Ã, Scacchia F: Economics of biomass energy utilization in combustion and gasification plants: effects of logistic variables. Biomass and Bioenergy 2005, 28:35-51.

14. Wang $L$, Weller $C L$, Jones DD, Hanna MA: Contemporary issues in thermal gasification of biomass and its application to electricity and fuel production. Biomass and Bioenergy 2008, 32:573-581.

15. Searcy E, Flynn P: The Impact of biomass availability and processing cost on optimum size and processing technology selection. Appl Biochem Biotechnol 2009, 154:271-286.

16. Uddin SN, Barreto L: Biomass-fired cogeneration systems with $\mathrm{CO} 2$ capture and storage. Renew Energy 2007, 32:1006-1019.

17. Faaij A: Modern biomass conversion technologies. Mitig Adapt Strat Glob Chang 2006, 11:343-375

18. Kazi FK, Fortman JA, Anex RP, Hsu DD, Aden A, Dutta A, Kothandaraman G Techno-economic comparison of process technologies for biochemical ethanol production from corn stover q. Fuel 2010, 89:S20-\$28.

19. Canilha L, Santos VT, Rocha GJ, e Silva Almeida J, Giulietti M, Silva S, Felipe MG, Ferraz A, Milagres AMF, Carvalho W: A study on the pretreatment of a sugarcane bagasse sample with dilute sulfuric acid. I Ind Microbiol Biotechnol 2011, 38:1467-75.

20. Purchase BBS, Walford SN, Waugh EJ: An update on progress in the production of ethanol from bagasse. Proceedings of the South African Sugar Technologists' Association - June 1986, 1986(June):33-36.

21. Treasure T, Gonzalez R, Venditti R, Pu Y, Jameel H, Kelley S, Prestemon J: Co-production of electricity and ethanol, process economics of value prior combustion. Energy Conversion and Management 2012, 62:141-153.

22. Gnansounou E, Dauriat A, Wyman CE: Refining sweet sorghum to ethanol and sugar: economic trade-offs in the context of North China. Bioresour Technol 2005, 96:985-1002

23. Gírio FM, Fonseca C, Carvalheiro F, Duarte LC, Marques S, Bogel-Lukasik R: Hemicelluloses for fuel ethanol: a review. Bioresour Technol 2010, 101:4775-4800.

24. Kurian J, Minu A, Banerji A, Kishore W: Bioconversion of hemicellulose hydrolysate of sweet sorghum bagasse to ethanol by using Pichia stipitis NCIM 3497 and Debaryomyces hansenii SP. Bioresources 2010 5:2404-2416.

25. Nigam JN: Ethanol production from wheat straw hemicellulose hydrolysate by Pichia stipitis. J Biotechnol 2001, 87:17-27.

26. Rudolf A, Baudel H, Zacchi G: Simultaneous saccharification and fermentation of steam-pretreated bagasse using Saccharomyces cerevisiae TMB3400 and Pichia stipitis CBS6054. Biotechnol Bioeng 2008 99:783-790.

27. Mcmillan JDJ: Progress on Advanced Liquid Biofuels in the USA Biofuels In Presented at International Symposium on Alchohol Fuels (ISAF); 2013. Stellenbosch, South Afrca: ISAF; 2013.

28. Aden A, Ruth M, Ibsen K, Jechura J, Neeves K, Sheehan J, Wallace B, Montague L, Slayton A, Lukas J: Lignocellulosic Biomass to Ethanol Process Design and Economics Utilizing Co-Current Dilute Acid Prehydrolysis and Enzymatic Hydrolysis for Corn Stover Lignocellulosic Biomass to Ethanol Process
Design and Economics Utilizing Co-Current Dilute Acid Prehyd. Colorado, USA: National Renewable Energy Laboratory (NREL); 2002.

29. Dias MOS, Modesto M, Ensinas AV, Nebra SA, Maciel R, Rossell CEV: Improving bioethanol production from sugarcane: evaluation of distillation, thermal integration and cogeneration systems. Energy 2011, 36:3691-3703.

30. Grisales R, Cardona CA, Sanchez O, Guterrez L: Heat Integration of Fermentation and Recovery Steps for Fuel Ethanol Production from Lignocellulosic. Costa Verde, Brazil: 4th Mercosur Congress on Process Systems Engineering, EMPROMER; 2005.

31. Kemp I: Pinch Analysis and Process Integration: A User Guide on Process Integration for the Efficient Use of Energy. Butterworth-Heinemann, Burlington, USA: Elsevier; 2007.

32. March L: Introduction to Pinch by Linnhoff March. Northwich, United Kingdom: Linnhoff March LTD; 1998.

33. Sue D-C, Chuang C-C: Engineering design and exergy analyses for combustion gas turbine based power generation system. Energy 2004, 29:1183-1205

34. Richardson JW, Herbst BK, Outlaw UL, Anderson DP, Klose SL, Gill RC II: Risk Assessment in Economic Feasibility Analysis: The Case of Ethanol Production in Texas. Texas, USA: Agricultural and Food Policy Centre; 2006.

35. Richardson JW, Klose SL, Gray AW: An applied procedure for estimating and simulating multivariate empirical (mve) probability distributions in farm-level risk assessment and policy analysis. Journal of Agricultural and Applied Economics 2000, 2(August):299-315.

36. Amigun B, Petrie D, Görgens J: Economic risk assessment of advanced process technologies for bioethanol production in South Africa: Monte Carlo analysis. Renew Energy 2011, 36:3178-3186.

37. Petersen A: Comparisons of the Technical, Financial Risk and Life Cycle Assessments of Various Processing Options of Sugarcane Bagasse To Biofuels in South Africa. South Africa: Stellenbosch University; 2012

38. Pellegrini LF, de Junior SO, de Burbano JC: Supercritical steam cycles and biomass integrated gasification combined cycles for sugarcane mills. Energy 2010, 35:1172-1180.

39. South African Petroleum Industry Association (SAPIA): Annual Report Sandton, South Africa: 2012.

40. Eskom: Grid Access: Scaling up for large scale renewable energy uptake. In Presentation to South African Photovoltaic Industry Association (SAPVIA). Cape Town, South Africa: South African Photovoltaic Industry Association.

41. Nsaful F, Görgens JF, Knoetze JH: Comparison of combustion and pyrolysis for energy generation in a sugarcane mill. Energy Conversion and Management 2013, 74:524-534.

42. EPA: Biomass CHP Catalogue, Part 7: Representative Biomass CHP System Cost and Performance Profiles. Washington DC, USA: Combined Heat and Power Partnership; 2007.

43. Dornburg V, Faaij PC: Efficiency and economy of wood-fired biomass energy systems in relation to scale regarding heat and power generation using combustion and gasification technologies. Biomass and Bioenergy 2001, 21:91-108.

44. National Energy Regulatory of South Africa (NERSA) Consultation Paper Review of Renewable Energy Feed. In Tariffs. Pretoria, South Africa: Nersa Office; 2011

45. Justice S: Private Financing of Renewable Energy - A Guide for Policy Makers. Nairobi, Kenya: United Nations Environment Programme (UNEP); 2009.

46. Craig KR, Mann MK: Cost and Performance Analysis of Biomass-Based Integrated Gasification Combined-Cycle (BIGCC) Power Systems Cost and Performance Analysis of Biomass-Based Integrated Gasification Combined-Cycle (BIGCC) Power Systems. Colorado, USA: National Renewable Energy Laboratory; 1996.

47. Leibbrandt NH: Techno-Economics Study for Sugarcane Bagasse to Liquid Biofuels in South Africa: A Comparison between Biological and Thermochemical Process Routes. Stellenbosch, South Africa: University of Stellenbosch; 2010

48. Diedericks D, Rensburg EV, Görgens JF: Fractionation of sugarcane bagasse using a combined process of dilute acid and ionic liquid treatments. Appl Biochem Biotechnol 2012, 167:1921-1937.

49. Oliveira FMV, Pinheiro IO, Souto-maior AM, Martin C, Gonçalves AR, Rocha GJM: Industrial-scale steam explosion pretreatment of sugarcane straw for enzymatic hydrolysis of cellulose for production of second generation ethanol and value-added products. Bioresour Technol 2013, 130:168-173. 
50. Wienese A, Purchase B, Wienese A, Purchase BS: Renewable Energy: An Opportunity for The South African Sugar Industry? In Proceedings of the South African Sugar Technologists' Association (SASTA), Volume 78. Mount Edgecombe, South Africa: SASTA; 2004:39-54.

51. Van der Westhuizen WA: A Techno-Economic Evaluation of Integrating First and Second Generation Bioethanol Production from Sugarcane In Sub-Saharan Africa. Stellenbosch, South Africa: Stellenbosch University; 2012

52. South African Sugar Mills. www.huletts.co.za/ops/south_africa/mills/ felixton.asp.

53. Seabra JEA, Tao L, Chum HL, Macedo IC: A techno-economic evaluation of the effects of centralized cellulosic ethanol and co-products refinery options with sugarcane mill clustering. Biomass and Bioenergy 2010, 34:1065-1078.

54. Mendes AGP: Dust explosions. In Proceedings of The South African Sugar Technologists' Association (SASTA) Congress: Volume 74, 1999. Mount Edgecombe, South Africa: SASTA; 1999:282-288.

55. Department of Environmental Affairs and Tourism: AQA Implementation: Listed Activities and Minimum Emission Standards. Draft schedule for section 21 Air Quality Act, Rev;: Department of Environmental Affairs and Tourism. Pretoria, South Africa: 2008

56. Nsaful F: Process Modelling Of Sugar Mill Biomass to Energy Conversion Processes and Energy Integration of Pyrolysis. Stellenbosch, South Africa: Stellenbosch University; 2012

57. Kreutz TG, Larson ED, Liu G, Williams RH: Fischer-Tropsch Fuels from Coal and Biomass. In 25th Annual International Pittsburgh Coal Conference: August 2008. Pittsburgh, USA: 2008

58. Mann MK, Spath SL: Life Cycle Assessment of a Biomass Gasification Combined-Cycle System. Colorado, USA: National Renewable Energy Laboratory; 1997.

59. Li X, Grace JR, Lim CJ, Watkinson AP, Chen HP, Kim JR: Biomass gasification in a circulating Fluidized bed. Biomass and Bioenergy 2004, 26:171-193.

60. Rodrigues M, Walter A, Faaij A: Performance evaluation of atmospheric biomass integrated gasifier combined cycle systems under different strategies for the use of low calorific gases. Energy Conversion and Management 2007, 48:1289-1301.

61. Fagbenle RL, Oguaka ABC, Olakoyejo OT: A thermodynamic analysis of a biogas-fired integrated gasification steam injected gas turbine (BIG/STIG) plant. Applied Thermal Engineering 2007, 27:2220-2225.

62. Lugo-Leyte R, Zamora-Mata JM, Toledo-Vela'zquez M, Salazar-pereyra M, Torres-aldaco A: Methodology to determine the appropriate amount of excess air for the operation of a gas turbine in a wet environment. Energy 2010, 35:550-555.

63. Polyzakis AL, Koroneos C, Xydis G: Optimum gas turbine cycle for combined cycle power plant. Energy Conversion and Management 2008 49:551-563.

64. Ree RV, Oudhuis AB, Faaij A, Curvers APW: Modelling of a Biomass Integrated Gasifier Combined Cycle (BIG/CC) System with the Flow sheet Simulation Programme Aspen Plus. Petten, Netherlands: Energy research Centre of the Netherlands (ECN); 1995.

65. Leibbrandt NH, Knoetze JH, Gorgens JF: Comparing biological and thermochemical processing of sugarcane bagasse: an energy balance perspective. Biomass and Bioenergy 2011, 35:2117-2126.

66. Gunarathne DS, Chmielewski JK, Yang W: High Temperature Air/Steam Gasification of Steam Exploded Biomass. Livomo, Italy: International Flame Research Foundation; 2013:1-14.

67. Aguilar R, Ramırez J, Garrote G, Vazquez M: Kinetic study of the acid hydrolysis of sugar cane bagasse. J Food Eng 2002, 55:309-318.

68. Tricket R: Utilisation of Bagasse for the Production of C5 and C6 Sugars. Durban, South Africa: University of Natal; 1982.

69. Lavarack BP, Gri GJ, Rodman D: The acid hydrolysis of sugarcane bagasse hemicellulose to produce xylose, arabinose, glucose and other products. Biomass and Bioenergy 2002, 23:367-380

70. Carrasco C, Baudel HM, Sendelius J, Modig T, Galbe M, Zacchi G, Liden G: SO2 catalyzed steam pretreatment and fermentation of enzymatically hydrolyzed sugarcane bagasse. Enzyme Microb Technol 2010, 46:64-73

71. Ferreira-leitão V, Perrone CC, Rodrigues J, Paula A, Franke M, Macrelli S, Zacchi G: An approach to the utilisation of $\mathrm{CO} 2$ as impregnating agent in steam pretreatment of sugar cane bagasse and leaves for ethanol production. Biotechnol Biofuels 2010, 3:7.
72. Laser M, Schulman D, Allen SG, Lichwa J, Antal MJ, Lynd LR: A comparison of liquid hot water and steam pretreatments of sugar cane bagasse for bioconversion to ethanol. Bioresour Technol 2002, 81:33-44.

73. Rocha GJM, Martín C, Vinícius FN, Gómez EO, Gonçalves AR: Mass balance of pilot-scale pretreatment of sugarcane bagasse by steam explosion followed by alkaline delignification. Bioresour Technol 2012, 111:447-452.

74. Humbird D, Davis R, Tao L, Kinchin C, Hsu D, Aden A, Schoen P, Lukas J, Olthof B, Worley MD: Sexton and DD: Process Design and Economics for Biochemical Conversion of Lignocellulosic Biomass to Ethanol Process Design and Economics for Biochemical Conversion of Lignocellulosic Biomass to Ethanol. Colorado, USA: National Renewable Energy Laboratory; 2011.

75. Preez JC, Driessel BV, Prior BA: Applied microbiology biotechnology ethanol tolerance of Pichia stipitis and Candida shehatae strains in fed-batch cultures at controlled low dissolved oxygen levels. Appl Microbiol Biotechnol 1989, 30:53-58.

76. Shevchenko SM, Chang K, Robinson J, Saddler JN: Optimization of monosaccharide recovery by post-hydrolysis of the water-soluble hemicellulose component after steam explosion of softwood chips. Bioresour Technol 2000, 72:207-211.

77. Martin C, Galbe M, Nilvebrant N, Jonsson L: Comparison of the fermentability of enzymatic hydrolyzates of sugarcane bagasse pretreated by steam explosion. Appl Environ Microbiol 2002, 98-100:699-716.

78. Richardson JW, Lemmer WJ, Outlaw JL: Bioethanol production from wheat in the winter rainfall region of South Africa: a quantitative risk analysis. International Food and Agribusiness Management Review 2007, 10:181-204.

79. Nilverbrant N, Persson P, Reimann A, De Sousa F, Gorton L, Jonsson J: Limits for alkaline detoxification of dilute-acid lignocellulose hydrolysates. App/ Biochem Biotechnol 2003, 105-108:615-628.

80. Nigam JN: Ethanol production from hardwood spent sulfite liquor using an adapted strain of Pichia stipitis. J Biotechnol 2001, 26:145-150.

81. Alriksson B, Horvath I, Sjode A, Nilverbrant N, Jonsson L: Ammonium hydroxide detoxification of spruce acid hydrolysates. Appl Biochem Biotechnol 2005, 121-124:911-922.

82. Tantirungkij M, Izuishi T, Seki T, Yoshida T: Applied microbiology biotechnoiogy fed-batch fermentation of xylose by a fast-growing mutant of xylose-assimilating recombinant Saccharomyces cerevisiae. Appl Microbiol Biotechnol 1994, 8:8-12.

83. Mcaloon A, Taylor F, Yee W, Regional E, Ibsen K, Wooley R, Biotechnology N: Determining the Cost of Producing Ethanol from Corn Starch and Lignocellulosic Feedstocks Determining the Cost of Producing Ethanol from Corn Starch and Lignocellulosic. Colorado, USA: National Renewable Energy Laboratory; 2000.

84. Aspen Technology Inc (Manufacturer): AspenPlus ${ }^{\oplus}$, Aspen/carus ${ }^{\oplus}$. 2008. http:// www.aspentech.com/products/aspen-plus.aspx.

85. Aboyade A: Co-Gasification of Coal and Biomass: Impact on Condensate and Syngas Production. Stellenbosch, South Africa: University of Stellenbosch; 2012

86. Chen C, Y-qi J, J-hua Y, Chi Y: Simulation of municipal solid waste gasification for syngas production in fixed bed reactors. J Zhenjiang Univ Sci B 2010, 11:619-628.

87. IChemE: Pinch Point Analysis Spreadsheet. Rugby, United Kingdom: Institute of Chemical Engineers; 2006

88. Peters and Timmerhaus: Analysis of cost estimation profitability, alternative investments and replacements optimum design and design strategy. In Plant Design and Economics for Chemical Engineers. 5th edition. Columbus, USA: McGraw Hill; 1997.

89. Richardson JW, Schumann K, Feldman P: Simeter - Simulation \& Econometrics To Analyze Risk. Texas USA: Simetar, Inc; 2008.

90. Bailey D: Issues Analysis of Retrofitting Once-Through Cooled Plants with Closed-Cycle Cooling. Electric Power Research Institute: USA; 2007.

91. Ridgway S: Projected Capital Costs of a Mist Lift OTEC Power Plant. New York, USA: The American Society of Mechanical Engineers; 1984.

92. Al-Riyami BA, Klimes J, Perry S: Heat integration retrofit analysis of a heat exchanger network of a fluid catalytic cracking plant. Applied Thermal Engineering 2001, 21:1449-1487.

93. Rhodes JS, Keith DW: Engineering economic analysis of biomass IGCC with carbon capture and storage. Biomass and Bioenergy 2005, 29:440-450.

94. Eskom Tariffs and Charges. http://www.eskom.co.za/CustomerCare/ TariffsAndCharges/Pages/Tariff_History.aspx.

95. CEPEA - Centro de Estudos Avancados em Economia Aplicada. http:// www.cepea.esalq.usp.br/xls/SaaofmensalUS.xls. 
96. State of Nebraska Official Website. http://digitalcommons.unl.edu/cgi/ viewcontent.cgi?article $=1033 \&$ context=imsediss.

97. Center for Agricultural and Rural Development, Historical Ethanol Prices. http://www.card.iastate.edu/research/bio/tools/download_eth_csv.aspx.

98. Producer Purchases Index. http://beta2.statssa.gov.za/timeseriesdata/Excell/ P0142.1\%20PP|\%20to\%202012\%20-\%20discontinued.zip.

99. South African Reserve Bank: Historical Exchange and Interest Rates. http://www.resbank.co.za/Research/Rates/Pages/SelectedHistoricalExchange AndlnterestRates.aspx.

100. Department of Minerals and Energy: Biofuels Industrial Strategy of the Republic of South Africa. Pretoria, South Africa: 2007.

101. Eberhard A: Grid-connected renewable energy in South Africa. In Presentation at the International Finance Corporation (IFC). Washington 2013. Washington, USA: IFC; 2013

doi:10.1186/1754-6834-7-105

Cite this article as: Petersen et al:: Techno-economic comparison of ethanol and electricity coproduction schemes from sugarcane residues at existing sugar mills in Southern Africa. Biotechnology for Biofuels 2014 7:105.

\section{Submit your next manuscript to BioMed Central and take full advantage of:}

- Convenient online submission

- Thorough peer review

- No space constraints or color figure charges

- Immediate publication on acceptance

- Inclusion in PubMed, CAS, Scopus and Google Scholar

- Research which is freely available for redistribution 